\title{
A fish for all seasons: spatial and temporal variation in patterns of demographic heterogeneity for Retropinna retropinna
}

by

Christopher John McDowall

A thesis submitted to the Victoria University of Wellington in partial fulfilment of the requirements for the degree of Master of Science in Marine Biology

Victoria University of Wellington

(December 2016) 



\section{ABSTRACT}

Demographic heterogeneity can have big effects on population dynamics, but for most species we have limited understanding of how and why individuals vary. Variation among individuals is of particular importance for stage-structured populations, and/or where species have 'complex life-cycles'. This is especially relevant in the case of amphidromous fishes that typically spawn in river mouths and estuaries, develop at sea and return to freshwater to finish development. These fish face strong selection pressures as they negotiate challenges around dispersal and development in order to reproduce successfully. Quantifying variation amongst individual fish can improve understanding of their population dynamics and suggest possible drivers of variation.

I evaluate patterns and sources of variation in demographic attributes of the New Zealand smelt (Retropinna retropinna). $R$. retropinna is an amphidromous fish that is endemic to New Zealand. While most populations have a sea-going larval stage, a number of landlocked freshwater populations occur, with the largest landlocked population residing in Lake Taupo. Here $R$. retropinna are presented with a variety of littoral feeding/spawning habitats and environmental conditions that may vary across distinct regions of the lake. In addition, the protracted spawning period for this species in Lake Taupo (occurring over eight months of the year) provides additional scope for seasonal variation to influence demographic attributes of individuals.

I sampled $R$. retropinna from discrete coastal habitats (beach or river) that were located in the eastern, southern and western regions of the lake. I evaluated patterns of variation in the size-structure, age-structure and morphology of $R$. retropinna among habitats and/or regions across Lake Taupo. I used otoliths to reconstruct demographic histories (ages, growth rates, hatch dates) of individuals, and used a set of statistical models to infer spatial variation in demographic histories. I found differences in size and age structure between regions, and a temporal effect of hatch date on larval/juvenile growth rates.

In addition, I obtained samples of $R$. retropinna from a sea-going population at the Hutt river mouth (sampled fish were presumed to be migrating upstream after their 
development period in Wellington Harbour and/or adjacent coastal environments). While Lake Taupo is large, deep, fresh, oligotrophic and strongly stratified for 8-9 months outside of winter, Wellington Harbour is less than a sixth of the area, shallow, saline, eutrophic and never stratified. These greatly differing environmental conditions led me to expect that these systems' $R$. retropinna populations would carry significantly different demographic attributes. I compared the hatching phenology, recruitment age, body morphology, and individual growth histories (reconstructed from otoliths) of $R$. retropinna sampled from Lake Taupo and Wellington Harbour. I explored the relationships between demographic variation and environmental variation (water temperature, chlorophyll a) for the two systems and found that this additional environmental information could account for much of the seasonal variation in daily otolith increment widths of $R$. retropinna. My results also suggest that while the two sampled populations likely share similar hatching and spawning phenologies, individuals from Lake Taupo tend to grow more slowly, particularly during winter, and end up smaller than sea-going fish sampled near Wellington. I speculate that these differences reflect variation in food supply (zooplankton may be limited in Lake Taupo over winter).

Overall, my results demonstrate a high degree of variation in morphological and life-history traits within a single species, potentially driven by an interaction between environmental variation and timing of development. My work contributes to a growing body of literature on demographic heterogeneity, and may help to inform the management of landlocked populations of $R$. retropinna in Lake Taupo. 


\section{ACKNOWLEDGEMENTS}

\section{I would like to thank the following people for their indispensable support.}

Conor Neilson - for helping me with sampling in Taupo, donating your fish, convincing me to learn to use $\mathrm{R}$, and being super helpful when necessary.

Daniel McNaughtan - for sharing your expertise on all things otolith, fieldwork and fish related.

Emily Watson - for helping me see the big picture, for looking after me, and for your (completely justified) tough love.

Jeff Shima - for being an inspiring, encouraging and patient supervisor.

Margaret and Lloyd Watkins - for letting me stay at your bach in Taupo.

Mark Kaemingk - for persuading me to join the Shima lab, for being a great pro bono mentor, and for your help with this manuscript (which I could have heeded more).

Michel Dedual - for being very supportive with my research plans, and for letting me borrow your seine net.

Ngatoru Wall - for taking me out to Lake Rotongaio and warning me about the loose sand on the vehicle track.

Sam McDowall - for helping me with sampling in Taupo, and for keeping me from taking myself too seriously.

The SBS technicians - for helping me get my H\&S sorted out.

The Shima lab group - for being a great bunch of people to know and learn from.

Topia Rameka, Alice Barnett and the Tuwharetoa Maori Trust Board - for being very supportive of my research plans.

Vincent Wood - for donating your fish. 
"...or let the fish in the sea inform you.

Which of all these does not know

that the hand of the Lord has done this?

In his hand is the life of every creature

and the breath of all mankind."

Job 12: 8-10 


\section{TABLE OF CONTENTS}

CHAPTER 1: GENERAL INTRODUCTION .............................................1

1.1 DEMOGRAPHIC HETEROGENEITY FOR STAGE STRUCTURED POPULATIONS .............................................. 1

1.2 KEY CHARACTERISTICS OF RETROPINNA RETROPINNA..................................................................... 2

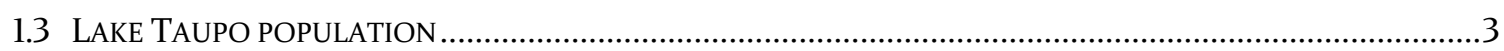

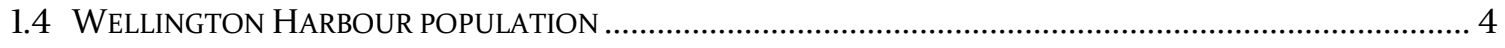

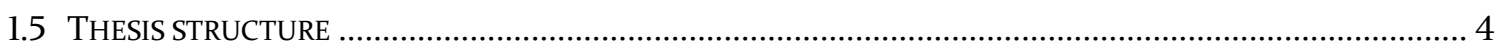

CHAPTER 2: SPATIAL AND TEMPORAL VARIATION IN AGE AND SIZE

STRUCTURE, MORPHOLOGY AND GROWTH ...................................... 5

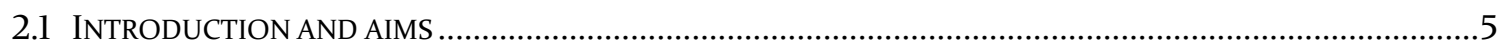

2.1.1 Spatial and temporal variation .............................................................................................

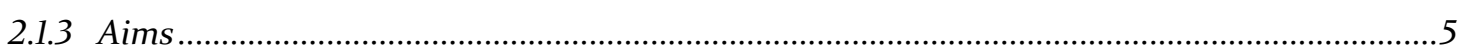

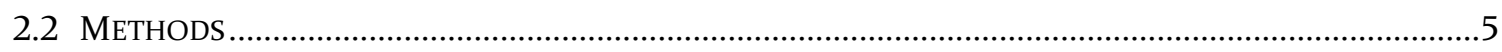

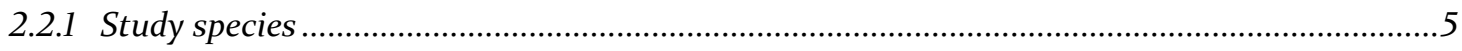

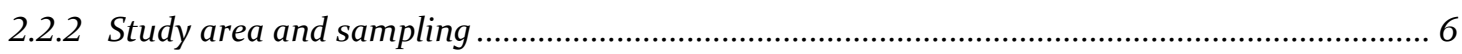

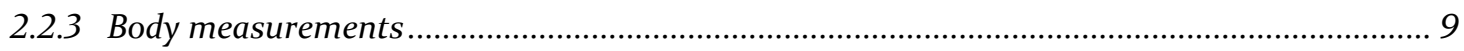

2.2.4 Otolith preparation and daily increments ....................................................................... 10

2.2.5 Age and size structure by region and habitat .......................................................................11

2.2.6 Morphological differences by region and habitat .................................................................11

2.2.7 Otolith growth rate differences by age, hatch phenology and region ................................... 12

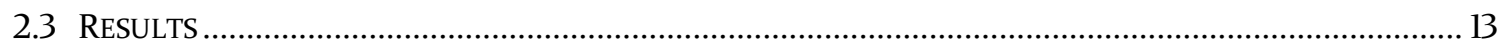

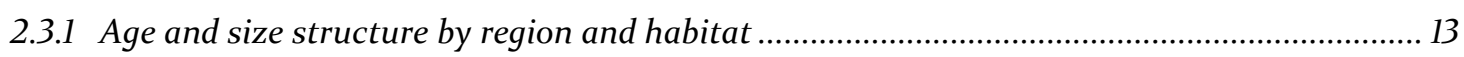

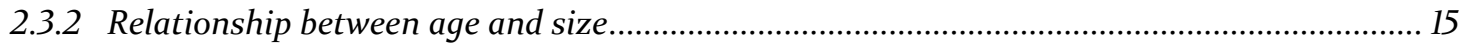

2.3.3 Morphological differences by region and habitat ................................................................. 16

2.3.4 Otolith growth rate differences by age, hatch date and region ............................................2 20

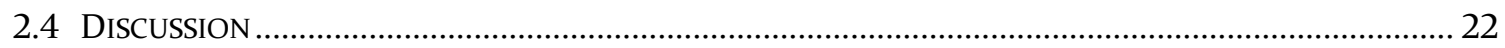

CHAPTER 3: INDIVIDUAL VARIATION BETWEEN TWO POPULATIONS......25

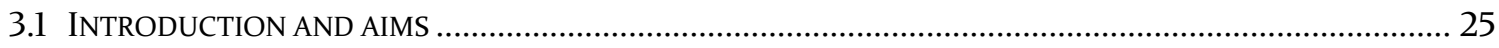

3.1.1 Seasonality, morphs, and individual variation ………..........................................................25 


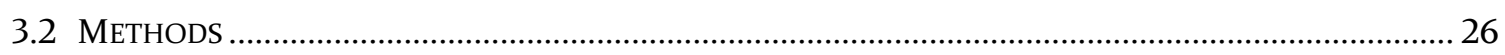

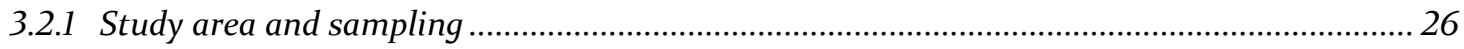

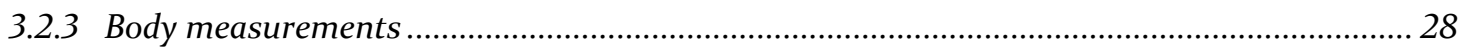

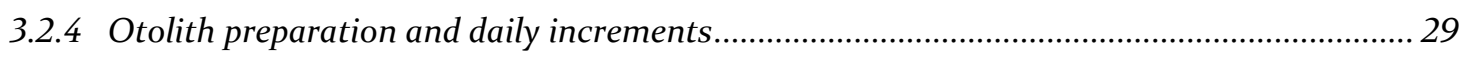

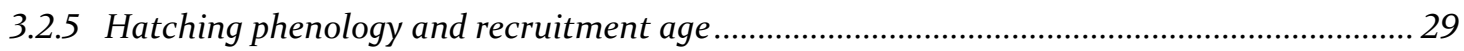

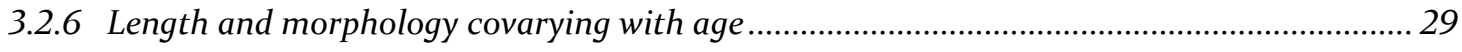

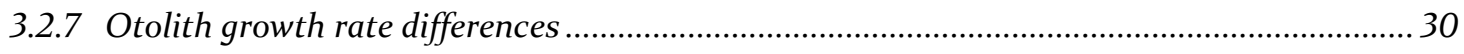

3.2.8 Temperature and chlorophyll a data ............................................................................... 31

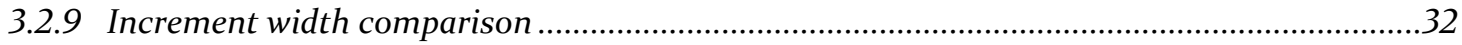

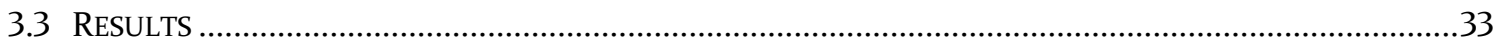

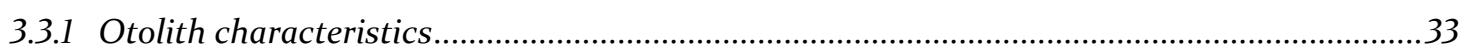

3.3.2 Hatching phenology and recruitment age .......................................................................34

3.3.3 Length and morphology covarying with age ..............................................................35

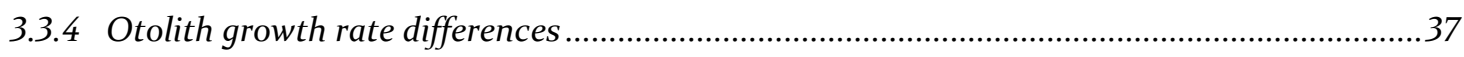

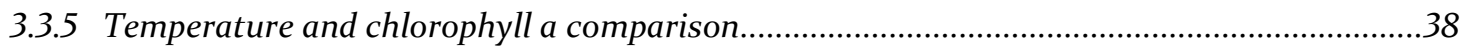

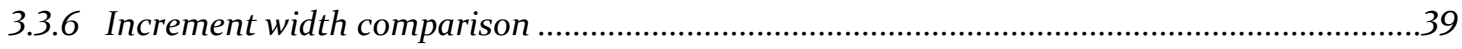

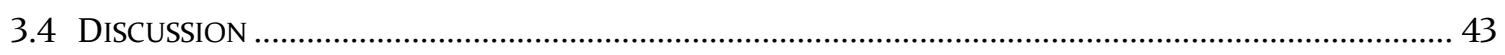

CHAPTER 4: GENERAL CONCLUSIONS ..................................................45

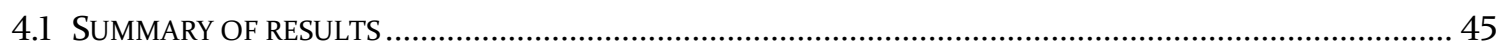

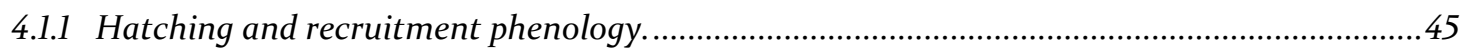

4.1.2 Effect of hatch date $v$ s region on growth rate ................................................................ 45

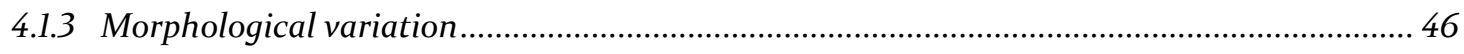

4.1.4 Environmental variables and increment widths ............................................................ 46

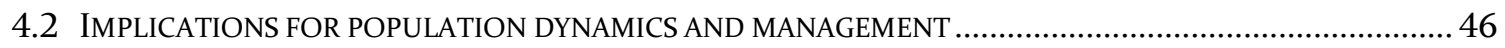

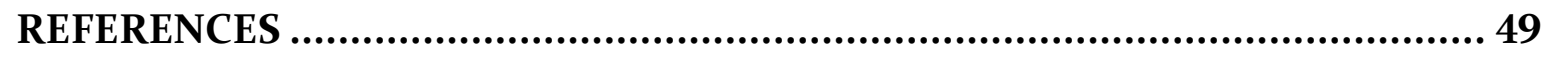




\section{LIST OF TABLES}

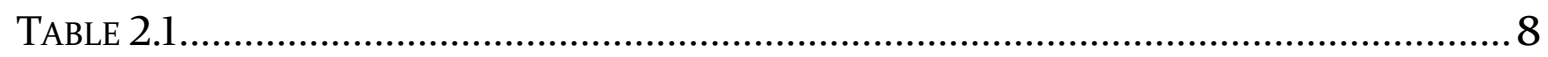

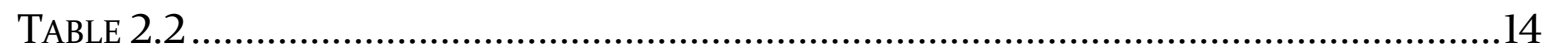

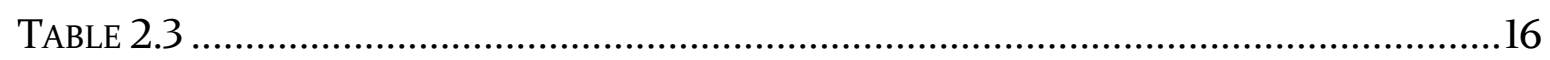

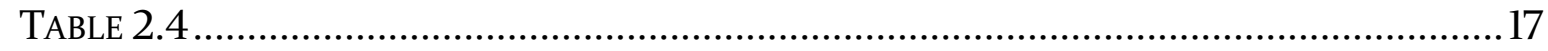

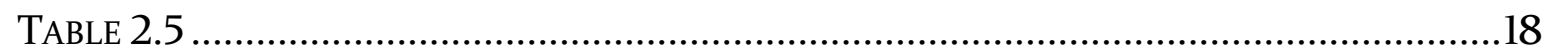

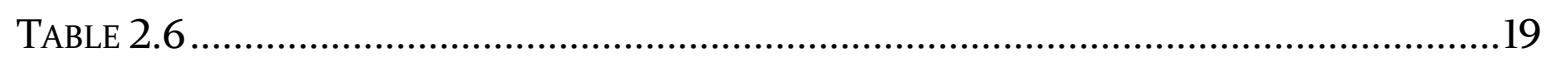

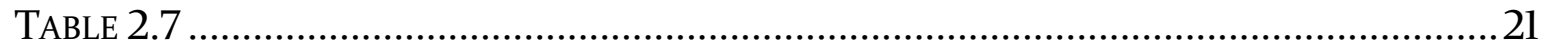

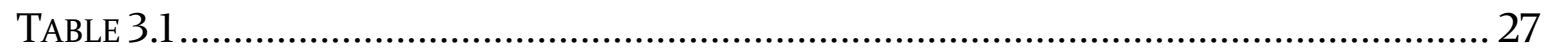

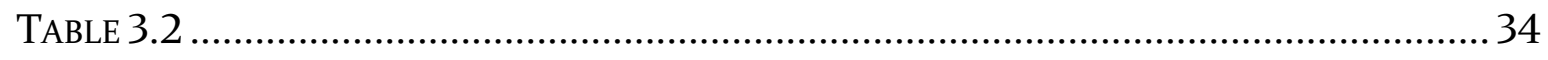

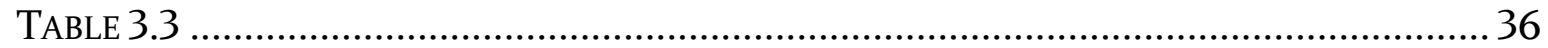

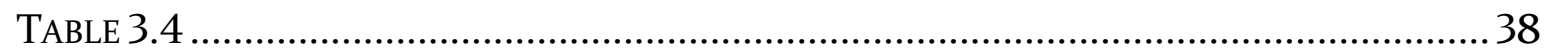

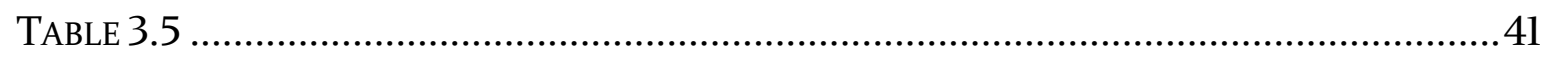

\section{LIST OF FIGURES}

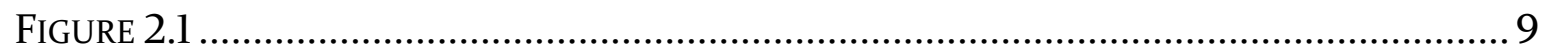

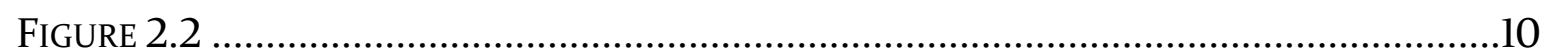

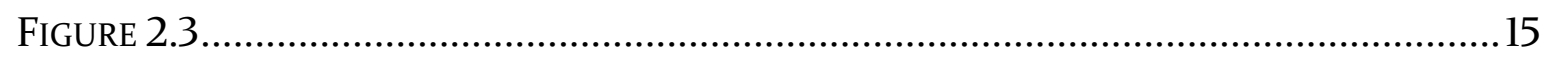

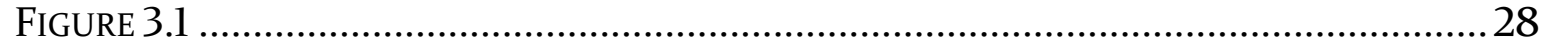

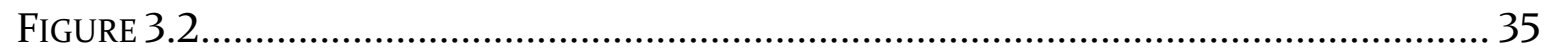

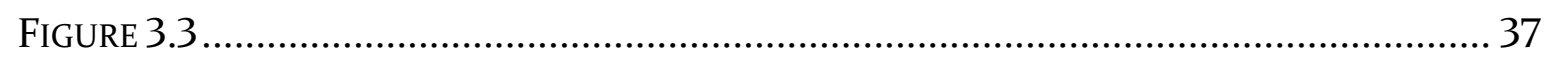

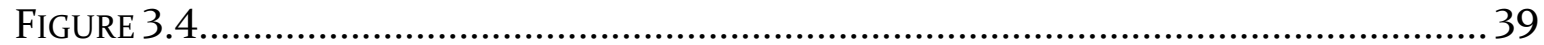

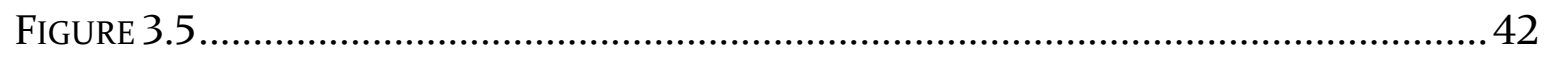

\section{LIST OF MODELS}

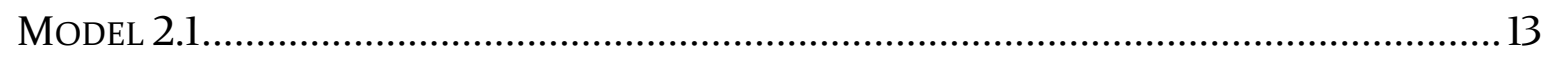

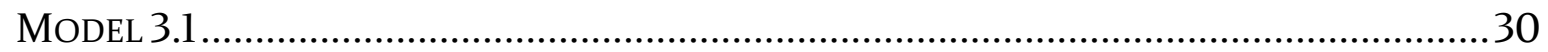

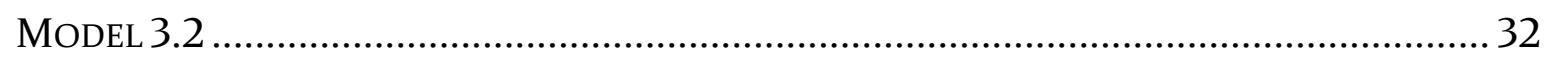

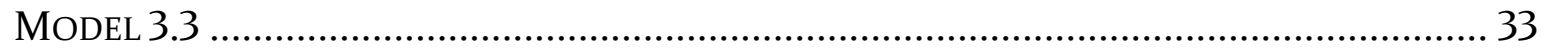





\section{CHAPTER 1: GENERAL INTRODUCTION}

\subsection{Demographic heterogeneity for stage structured populations}

The effect of individual variation on population dynamics has long been recognised (Haldane 1924; Norton 1928). More recently, researchers have used measures of individual variation to formally characterise levels of demographic heterogeneity in population models (Wilson \& MacArthur 1967; Roughgarden 1971). However populations of many species are stage-structured, meaning that demographic rates (e.g. birth rates, death rates) will change significantly between the life-stages of individuals. This has necessitated the development of models which can account for age structure as a contributor to demographic heterogeneity (Leslie 1945; Charlesworth 1980; Caswell 2001). These models have been successfully applied to a wide range of populations, including Drosophila flies (Kern et al. 2001), plants with seed dormancy (Harper \& White 1974), pathogenic bacteria (Keeling \& Rohani 2008), humans (Vaupel et al. 1979), and sheep on a small Scottish Island (Ozgul et al. 2009). Models that account for demographic heterogeneity in stage-structured populations may offer far more accurate representations of population dynamics (Vaupel \& Yashin 1985; Metcalf \& Pavard 2007).

These models can be a powerful tool for understanding the environmental drivers that shape the dynamics of populations, especially at a time when many populations are under pressure from environmental change and/or direct human exploitation (Conner \& White 1999). However, their utility is often limited by a lack of intensive stagestructured data at the individual level (Benton et al. 2006). Populations of teleost fish offer an opportunity in this area, as their otoliths ('ear stones') contain daily and/or yearly records of incremental growth, yielding individual growth histories across multiple stages of life (Reibisch 1899; Pannella 1971; Campana \& Neilson 1985). Otolith growth histories have been particularly useful for studying the larval stages of fish populations, where mortality rates are very high (often >99\% [Dahlberg 1979; Houde 1989]). This has led researchers to build both closed (Kendall et al. 2011; Stover, et al 
2012) and open models (Noonburg et al. 2015) that include demographic heterogeneity when considering the larval stages of fish populations. Models of this sort can identify patterns and potential drivers of demographic heterogeneity, and lead to useful management tools.

In this thesis I will investigate patterns and potential drivers of demographic heterogeneity for two populations of the New Zealand smelt (Retropinna retropinna), a teleost fish with a complex life cycle and stage structured populations.

\subsection{Key characteristics of Retropinna retropinna}

Retropinna retropinna (order Osmeriformes) is a fish endemic to New Zealand (McDowall 1979) with an amphidromous life cycle, i.e. larvae hatch in estuaries and rivers, disperse and develop at sea, and recruit to freshwater as juveniles (McDowall 2007). However some 'landlocked' populations exist in freshwater systems with no access to the sea. Relative to populations with coastal access, landlocked populations may have different spawning seasons, size structure and meristic traits (McDowall 1979; Northcote \& Ward 1985; Ward et al. 1989; Ward et al. 2005; Tana \& Tempero 2013). Moreover, they may acquire these different characteristics within only a few generations of translocation to landlocked systems (McDowall 1990). Although populations of each 'morph' may occur sympatrically (e.g. Lake Waahi or in the upper Waikato River), this is only in cases where the migratory ecotype is living at the furthest extent of its range, perhaps limiting its ability to compete with a landlocked ecotype (Booker 2000).

$R$. retropinna have received relatively little research attention compared to other New Zealand native freshwater fish taxa. Better studied are the Galaxiids, a family also from the order Osmeriformes, many of whom exhibit a very similar amphidromous life cycle (McDowall 1990). In particular, only one paper has previously investigated daily otolith increments otolith microstructure for R. retropinna (Ward \& Boubee 1996) and the larval stage of their life cycle is poorly understood (Ward et al. 2005). However, there is some research into the otolith microstructure of and microchemistry for their congeners in Australia (Tonkin et al. 2008; Tonkin et al 2008; Tonkin et al. 2011). 
$R$. retropinna have also proven to be relatively resilient to anthropogenic impacts and introduced predators compared to other freshwater fish taxa endemic to New Zealand (Blair 2012). They are found in lakes, rivers and estuaries throughout the country and can quickly establish self-sufficient populations when newly introduced to an area (McDowall 1990; Rowe 1993). They have a high rate of fecundity, a one year generation time (Ward \& Boubee 1996), can feed on a wide variety of zooplankton and other invertebrates (Cryer 1988) and an eight month spawning season (Stephens 1984). Overall, $R$. retropinna is an effective 'weedy' species that is able to flexibly cope with population pressures, and is likely to show size and/or age structure, morphological variation and differential growth rates.

\subsection{Lake Taupo population}

The closed population of landlocked $R$. retropinna in New Zealand's Lake Taupo was established through intentional translocation in 1934 and rapidly conformed to the general landlocked ecotype (Burstall 1950). The intent of the translocation was to provide an additional forage species for the lake's exotic salmonid fishery (Burstall 1950). Although successful from this perspective, direct or indirect competition from $R$. retropinna (combined with predation pressure from the salmonids) is likely responsible for the collapse of Lake Taupo's Galaxias brevipinnis fishery (Rowe; Strickland 1993).

Lake Taupo is drained by the Waikato River, but any upstream dispersal of $R$. retropinna is prevented by eight hydroelectric dams and the Huka Falls - although there is likely some downstream dispersal into the landlocked populations that exist in the hydroelectric reservoirs (Booker 2000). Lake Taupo presents a large and diverse aquatic environment to $R$. retropinna. Juveniles and adults shoal together at the shore of the lake in order to feed and/or spawn, but may select either a beach or a river habitat. Furthermore, the eastern, southern and western regions of the lake are all distinct in terms of the quantity of beach or river habitat they provide, are differently oriented in relation to prevailing winds and currents, and are potentially far enough away from each other to preclude the even dispersal of planktonic larvae around the lake (Jolly 1967; Stephens 1984). 


\subsection{Wellington Harbour population}

Sea-going populations of $R$. retropinna are found in most of New Zealand's coastal aquatic habitats, with the best-studied being in the lower reaches of the Waikato River (McDowall 1990). The extent to which these populations are demographically and/or genetically connected with each other is unknown, but populations of congenerics in Australia are thought to have low genetic connectivity (Hammer et al. 2007). Galaxias maculatus (which shares a similar lifecycle to R. retropinna [McDowall 1990]) sampled from harbour locations around the North Island of New Zealand (including Wellington Harbour) may be younger and faster growing than ones sampled from adjacent coastal sites (Kaemingk unpublished data 2015, Neilson unpublished data 2016). This suggests that there is some degree of demographic separation in-harbour and open coast populations for New Zealand's amphidromous fish taxa. The Hutt River (which empties into Wellington Harbour) contains the older juveniles and adults of a population of sea-going $R$. retropinna. This population is not the subject of any previous study, but likely has weak demographic connectivity with other populations, with a majority of larvae and younger juveniles probably remaining within Wellington Harbour.

\subsection{Thesis structure}

In the second chapter of this thesis, I will examine whether the population of $R$. retropinna in Lake Taupo exhibits any spatial or temporal patterns of demographic heterogeneity. I will do this by considering distinct geographic regions of Lake Taupo, the diversity of its aquatic habitat, and the long duration of $R$. retropinna's spawning season. In the third chapter of this thesis, I will see how demographic features differ between the landlocked $R$. retropinna population of Lake Taupo and the sea-going population of Wellington Harbour. I will also investigate some potential environmental drivers for these demographic differences. While both of these chapters shall contain some introduction and discussion of their main results, they are not intended as stand-alone scientific papers. Finally in the fourth chapter, I will discuss some of the wider implications and significance of my results. 


\section{CHAPTER 2: SPATIAL AND TEMPORAL VARIATION IN AGE AND SIZE STRUCTURE, MORPHOLOGY AND GROWTH}

\subsection{Introduction and aims}

In this chapter, I examine patterns of demographic heterogeneity in the Lake Taupo population of $R$. retropinna according to spatial and temporal patterns of variation.

\subsubsection{Spatial and temporal variation}

In freshwater systems, fish from adjacent lake/river habitats often exhibit divergent morphologies. These differences may persist due to a mix of demographic and evolutionary forces. For example, divergent morphologies can arise from spatial reproductive barriers and selection pressures (Schluter \& McPhail 1992; Hendry et al. 2002), priority effects (Kaemingk et al. 2012) and divergent phenologies (Bogner et al. 2016). In fish, divergent morphologies may manifest in terms of body shape, often with a fusiform (i.e. streamlined) body type suited to living in open water versus heavyset body types more suited to living on the benthos (Vogel 1994; Langerhans et al. 2003; Langerhans \& Reznick 2010). In addition to divergent morphologies, rates of growth may also vary (Mooij et al. 1994).

\subsubsection{Aims}

Using $R$. retropinna from Lake Taupo, I asked the following questions. 1) Do age and length vary spatially amongst regions and between habitat types? 2) Does morphology covary with age or size differently amongst regions and between habitat types? 3) Do otolith growth rates for pelagic larvae/juveniles covary with age, or with hatch phenology? Do they covary differently amongst regions?

\subsection{Methods}

\subsubsection{Study species}

Retropinna retropinna (the New Zealand smelt) is a fish endemic to New Zealand (McDowall 1979). It typically conforms to an amphidromous life cycle, where the 
adults spawn in shallow fresh or brackish water and larvae are transported out to sea. After 5-8 months at sea, the larvae return to freshwater as juveniles to mature and spawn at about one year of age. However non-migratory (or 'landlocked') populations also exist within the upper reaches of some rivers or within lakes lacking access to the sea (McDowall 1990; Ward et al. 2005; Booker 2000) - the later usually resulting from anthropogenic translocations (Strickland 1993). Landlocked $R$. retropinna still spawn in shallow water (i.e. in a river mouth or on a beach), but the larvae remain in fresh water until they settle to a beach or river mouth (McDowall 1990).

\subsubsection{Study area and sampling}

Lake Taupo is a large and deep temperate oligotrophic caldera lake in the central North Island of New Zealand, with surface area $616 \mathrm{~km}^{2}$, average depth $110 \mathrm{~m}$ and surface elevation 356m (White \& Downes 1977; Forsyth et al. 1983; Verburg \& Albert 2016). It is drained by the Waikato River, but any dispersal of fish from downstream populations is prevented by eight hydroelectric dams and the Huka Falls (Booker, 2000; Ward et al. 2005). R. retropinna were most likely introduced to the lake by Europeans in 1934 to improve the food supply for the salmonid fishery (Burstall 1950). However they may also have been introduced at an earlier date by Māori (Strickland 1993). This population has attracted little study (but see Jolly 1967 and Stephens 1984).

In Lake Taupo, larvae become planktonic upon hatching. Juveniles (about 15-30mm fork length) feed on pelagic zooplankton and live at low density, but adults (and larger juveniles ranging from $25-30 \mathrm{~mm}$ fork length) form dense shoals on beaches and in rivers or lagoons - likely in order to feed on larger prey (e.g. chironomid larvae) and to eventually spawn in the shallow water (Jolly 1967; Stephens 1984).

I employed a spatially structured sampling programme in which I collected $R$. retropinna from three pairs of sites around Lake Taupo (six sites in total [Table 2.1, Figure 2.1]). Each pair consisted of a beach habitat and a river habitat, about 25-50 metres away from each other. I defined beach habitats as areas of sandy beach at the plume of a stream or river (these being aggregation points for $R$. retropinna) and river habitats as areas of slow-moving water upstream of the mouth of the stream or river. I stratified each pair of sites within a 'geographical region' of Lake Taupo; the east (site 
IDs = EBeach, ERiver), south (site IDs = SBeach, SRiver) and west (site IDs = WBeach, WRiver). These sites were sampled over three days (5-7 November 2015).

I also included one additional unpaired site in the eastern region, from which I took two samples - once before (on 2 November 2015, site ID = Before) and once after (on 8 November, site ID = After) my sampling of the paired sites. I included these 'bracketing' samples to evaluate potentially confounding temporal variation in size or age structure across the main sampling period.

I used a standard seine net $(8.0 \mathrm{~m} \times 0.9 \mathrm{~m}$, with $2 \mathrm{~mm}$ mesh $)$ for all sampling. With one end of the net fixed on the bank, I dragged the other end into the water until the net was fully extended and perpendicular to the shoreline. Then I dragged the lakeward end of the net in a $90^{\circ}$ arc back to the bank. Low densities of $R$. retropinna at two sites (WRiver and WBeach) necessitated multiple tows (8 and 6 respectively) along a 20 metre stretch of shoreline to sample a sufficient number of $R$. retropinna (23 and 38 respectively). For all other sites, I caught $>100$ R. retropinna in the first tow (Table 2.1), and made no additional tows.

I sorted the contents of each tow and preserved $R$. retropinna in 99\% ethanol for further analysis. I immediately released any non-target taxa (e.g. Gobiomorphus cotidianus, Galaxias brevipinnis, Salmo trutta and Oncorhynchus mykiss); all by-catch was successfully released unharmed back to the water. I randomly selected a subsample of 30 R. retropinna from each target site (apart from WRiver, where only 23 were available) for further processing. Final sample sizes available for statistical analyses were typically less than 30 fish (Table 2.1 ) because some otoliths were unable to be reliably read (detailed later). 
Table 2.1. Lake Taupo samples. Given for each sample are its ID, region, habitat, locality, UTM coordinates, date of sampling and $\mathrm{n}$ (number of fish included in data analysis).

\begin{tabular}{|c|c|c|c|c|c|c|}
\hline $\begin{array}{l}\text { Sample } \\
\text { ID }\end{array}$ & Region & Habitat & Locality & $\begin{array}{l}\text { Latitude, } \\
\text { longitude }\end{array}$ & $\begin{array}{l}\text { Date of } \\
\text { sampling }\end{array}$ & $\mathbf{n}$ \\
\hline Before & East & Beach & Five Mile Bay & $\begin{array}{l}-38.771596 \\
176.075593\end{array}$ & $\begin{array}{l}\text { 2nd of Nov } \\
2015\end{array}$ & 24 \\
\hline After & East & Beach & Five Mile Bay & $\begin{array}{l}-38.771596 \\
176.075593\end{array}$ & $\begin{array}{l}\text { 8th of Nov } \\
2015\end{array}$ & 25 \\
\hline EBeach & East & Beach & $\begin{array}{l}\text { Whangaerorohea } \\
\text { Outlet }\end{array}$ & $\begin{array}{l}-38.805033 \\
176.060518\end{array}$ & $\begin{array}{l}5 \text { th of Nov } \\
2015\end{array}$ & 25 \\
\hline ERiver & East & River & Lake Rotongaio & $\begin{array}{l}-38.806028 \\
176.059949\end{array}$ & $\begin{array}{l}5 \text { th of Nov } \\
2015\end{array}$ & 29 \\
\hline SBeach & South & Beach & Kuratau Beach & $\begin{array}{l}-38.888579 \\
175.77258\end{array}$ & $\begin{array}{l}\text { 7th of Nov } \\
2015\end{array}$ & 25 \\
\hline SRiver & South & River & Kuratau River & $\begin{array}{l}-38.888087 \\
175.771861\end{array}$ & $\begin{array}{l}\text { 7th of Nov } \\
2015\end{array}$ & 25 \\
\hline WBeach & West & Beach & Waihaha Bay & $\begin{array}{l}-38.720181 \\
175.75140\end{array}$ & $\begin{array}{l}\text { 6th of Nov } \\
2015\end{array}$ & 25 \\
\hline WRiver & West & River & Waihaha River & $\begin{array}{l}-38.721795 \\
175.74844\end{array}$ & $\begin{array}{l}\text { 6th of Nov } \\
2015\end{array}$ & 23 \\
\hline
\end{tabular}




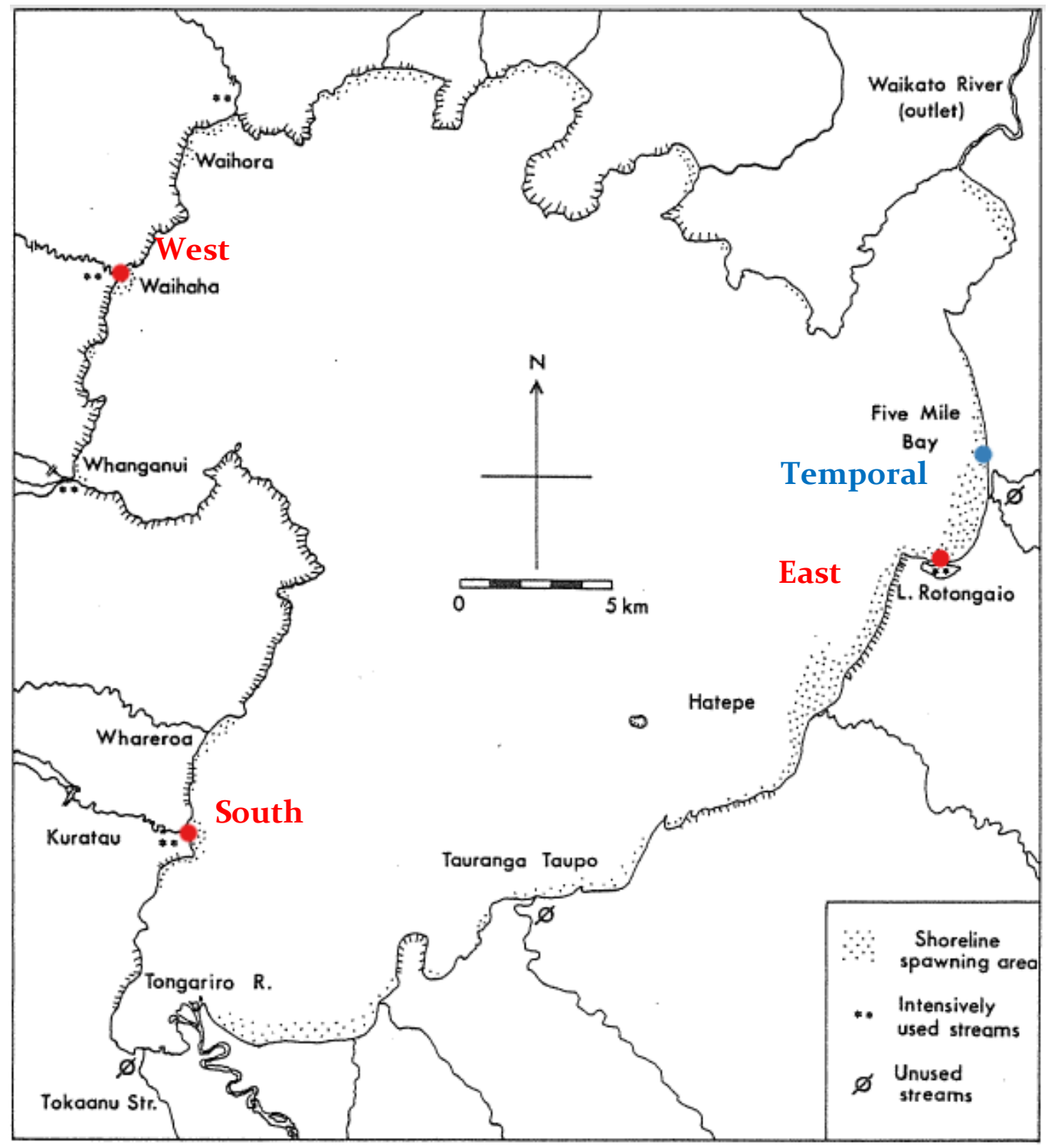

Figure 2.1. Map of Lake Taupo in New Zealand (adapted from Stephens 1984), showing major $R$. retropinna spawning areas (see inset for key). Shown in red are the three geographic regions where I sampled. Shown in blue is the temporal site, which I sampled from before and after sampling from the paired sites (see Table 2.1).

\subsubsection{Body measurements}

To estimate overall body size, I measured fork length. I estimated patterns of variation in additional morphological traits, and I evaluated morphological variation in relation to body size or age. Specifically, I measured head length and body depth (possibly indicative of fusiform shape [Vogel 1994; Langerhans \& Reznick 2010]) and eye diameter (possibly indicative of visual acuity [Pankhurst \& Montgomery 1994]). I 
photographed the lateral side of each selected $R$. retropinna using an Olympus TG-3 digital camera, and used ImageJ vl.50i (calibrated to a reference measurement in the photo) to digitally measure these variables (Figure 2.2).

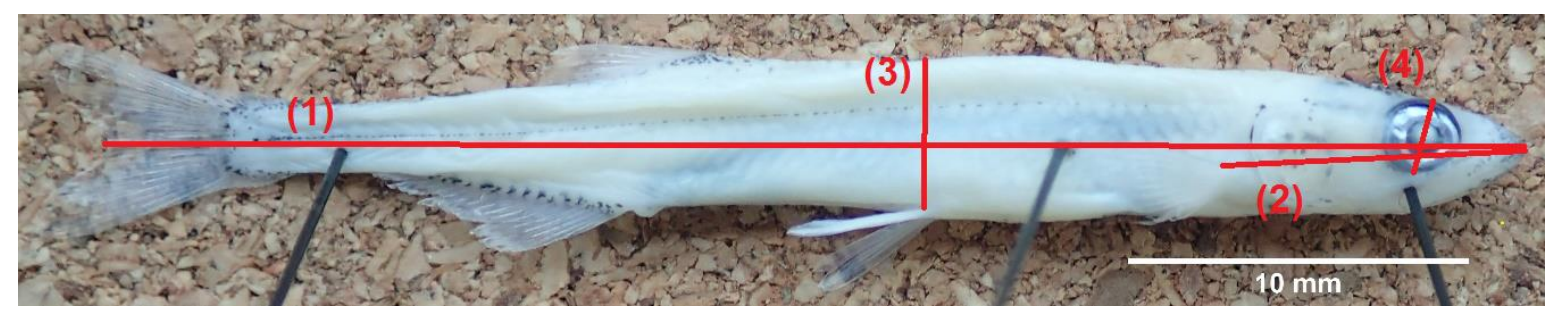

Key

\begin{tabular}{|c|c|c|}
\hline Measurement & Number & Definition \\
\hline Fork length & (1) & Distance from snout to fork of caudal fin \\
\hline Head length & (2) & Distance from snout to base of pectoral fin \\
\hline Body depth & (3) & $\begin{array}{l}\text { Perpendicular distance from dorsal to ventral side of body at } \\
\text { base of pelvic fin }\end{array}$ \\
\hline Eye diameter & (4) & $\begin{array}{l}\text { Diameter of eye, measured through the pupil from side nearest } \\
\text { top of head }\end{array}$ \\
\hline
\end{tabular}

Figure 2.2. Diagram (with key below) showing the four variables I measured for each $R$. retropinna. Measurements were precise to $0.01 \mathrm{~mm}$.

\subsubsection{Otolith preparation and daily increments}

To obtain estimates of age structure and growth rates, I reconstructed individual growth histories. I dissected both sagittal otoliths from each $R$. retropinna, and cleaned them in a $\mathrm{NaOH}$-buffered $15 \% \mathrm{H}_{2} \mathrm{O}_{2}$ solution. For each individual I randomly chose one otolith, embedded it in Buehler "EpoThin" epoxy, and ground down its distal surface with a diamond lapping film (using either $9 \mu \mathrm{m}$ or $3 \mu \mathrm{m}$ grade for the initial grind, then $1 \mu \mathrm{m}$ grade to polish) until the primordium was exposed. I then viewed each otolith at 1000x magnification in immersion oil using a Leica compound microscope connected to a Canon EOS 70D digital SLR camera.

For each otolith I photographed the anterior portion of its longitudinal axis from the centre to the edge, as this typically provided the longest and clearest transect for resolution of daily increments. I stitched 3 to 6 photographs into a composite image (using GIMP v2.8.0) in order to capture this transect. 
I used the Otolith M app in Image-Pro Premier v9.1 to count and measure daily increments from composite images. For all otoliths with high clarity at their core, the first visible daily increment was observed at 3.5 to $4.5 \mu \mathrm{m}$ from the primordium (i.e., the start of the transect). I made an assumption that this characteristic 'first increment' corresponded to hatching (Ward \& Boubee 1996). For otoliths with poorer clarity at the core, I inferred the locations of the putative hatch check and, in some cases, the first 5-15 daily increments using characteristic increment widths as measured from other otoliths, and/or visual information in from regions of the otolith that were not directly on the sampled transect. For each fish, I used otolith increment counts to estimate age in days, and subtracted this from the date of sampling to infer hatch date.

\subsubsection{Age and size structure by region and habitat}

I performed all of my statistical analyses in RStudio v0.99.903 (RStudio 2015).

To evaluate variation in age and/or size (fork length) of $R$. retropinna as a function of region and/or habitat, I used non-parametric K-sample Anderson-Darling tests, which evaluate whether two samples of data may be modelled as having come from the same distribution. I chose Anderson-Darling tests over the more conventional parametric ttest as the former are generally more powerful (Anderson \& Darling 1954; Scholz \& Zhu 2016). Using this test, I conducted pairwise comparisons between each of the levels of region (east vs south, east vs west, south vs west) and of habitat (beach vs river). I also used this approach to evaluate temporal variation in age and size across my period of sampling (i.e., using the bracketing samples collected before vs after the main period of sampling).

\subsubsection{Morphological differences by region and habitat}

To see whether the relationship between length and age was linear for $R$. retropinna, I evaluated a general linear model that predicted fork length as a function of age (for this analysis, I used my full set of samples from Lake Taupo, $n=201$ ). I evaluated the residuals for this relationship using plots and a Breusch-Pagan test, which tests the null hypothesis of homoscedasticity against an alternative hypothesis of heteroscedasticity (Breusch \& Pagan 1979; Zeileis \& Hothorn 2002). I interpreted homoscedastic residuals as evidence for a linear relationship between length and age for my set of samples. 
I evaluated variation in morphological traits of $R$. retropinna, among region and/or habitats within Lake Taupo. Because I wanted to control for variation in fish size in this analysis, I used analysis of covariance (ANCOVA), with size (fork length) as a covariate. This model makes an assumption of isometric growth of the traits of interest (i.e., trait size scales linearly with fork length). In addition, I evaluated variation in morphological traits using age as a covariate (and again, this model, assumes a linear relationship between trait size and age). For each version of the model (i.e., using either age or size as a covariate), I evaluated head length, body depth, eye diameter as the dependent variable, in separate tests. All models included region (with three levels: east, south or west) and habitat (with two levels: beach or river) as fixed effects, and with either age or length as a covariate.

In order to discriminate between the different levels of region (east, south, west) I used post hoc interaction contrasts (Marascuilo \& Levin 1970; Rosario-Martinez 2015) to compare the different levels of region while accounting for any interactions with habitat.

\subsubsection{Otolith growth rate differences by age, hatch phenology and region}

I evaluated variation in growth rates of early life history stages of $R$. retropinna (reconstructed from otoliths) as a function of age, hatch date, and region. Specifically, I modelled the otolith size-at-age (i.e., radius at a given daily increment) for individuals sampled from the three regions $(n=152)$, using a general linear mixed effects model from Pinheiro (2016) with restricted maximum likelihood estimation (Model 2.1). Mixed effects models include explicit fixed effects (as with traditional linear models), but aim to account for some of the model's residual error by adding one or more random effects.

To ensure that I was considering growth rates of early life history stages (i.e., pelagic larvae and/or juveniles), I considered only the first 100 days of post-hatch otolith growth for each fish in these analyses (my results [Table 2.3] suggest that fish of this age are $\sim 25 \mathrm{~mm}$ in fork length, consistent with sizes of early life history stages identified by (Jolly 1967; Stephens 1984). 


\section{Model 2.1}

$$
\text { radius } \sim \text { age } * \text { hatch date } * \text { region }+(1+\text { age } \mid \text { fish })+\text { error }
$$

For Model 2.1, the dependent variable 'radius' is the distance of each daily increment from the centre of the otolith in $\mu \mathrm{m}$ (i.e. otolith size-at-age), for each $R$. retropinna. The model includes 'age' (a covariate, modelled as a fixed effect) associated with each observation, 'hatch date', (another covariate, representing the calendar hatch date for each $R$. retropinna; these ranged from October 2014 - May 2015 and were coded as sequential numbers; fixed effect), and 'region' (fixed effect with three levels: east, south or west). These fixed effects were crossed, so the model also included two and threeway interactions between each of these variables.

I also include a random effect '1+age fish' as a variable to account for 'individual fish' (i.e., each fish had 100 consecutive daily observations of otolith size-at-age). This meant the model gave each individual fish a random intercept and slope for the dependent variable 'radius'. The slope allowed each individual fish to interact uniquely with each level of 'age', which avoids the assumption that each repeated measure of 'age' is independent from the others. Including the slope also allowed the model to include the complete size-at-age record for each individual, as opposed to using averaged growth rates for individuals (Weisberg et al. 2010).

\subsection{Results}

\subsubsection{Age and size structure by region and habitat}

Age and size (fork length) varied among regions for each pairwise comparison (Table 2.2). $R$. retropinna from the south were older and larger than those from the west, which in turn were older and larger than those from the east. Age and size did not vary between the bracketed samples (that were collected before and after all the other samples). This gives some assurance that there was no confounding temporal effect of sampling-time on age or size. Age and size did not differ significantly between habitats.

Despite this final result, age and size varied slightly between habitats for $R$. retropinna depending on region (Figure 2.3). In the west, beach individuals were generally larger 
and older than river ones. However for eastern and southern regions, there was a slight trend in the opposite direction. This raises the possibility that region and habitat interacted in predicting age and size. Other interactions between region and habitat will be explored further below.

Table 2.2. Results of $K$-sample Anderson-Darling tests between factor levels for time of sampling, region and habitat for the dependent variables age (in days) and size (fork length in $\mathrm{mm}$ ) of $R$. retropinna. Given for each test are the difference between means, the standardised AndersonDarling test statistic (T.AD) and a $p$ value. Results with $p<0.05$ are highlighted.

\begin{tabular}{|c|c|c|c|c|c|}
\hline Factor & $\begin{array}{l}\text { Factor level } \\
\text { pairs }\end{array}$ & $\begin{array}{l}\text { Dependent } \\
\text { variable }\end{array}$ & $\begin{array}{l}\text { Difference } \\
\text { between means }\end{array}$ & T.AD & $p$ value \\
\hline \multirow{2}{*}{$\begin{array}{l}\text { Time of } \\
\text { sampling }\end{array}$} & \multirow[t]{2}{*}{ Before - After } & Age & -8 & 0.639 & 0.1796 \\
\hline & & Size & -1.2 & 1.361 & 0.0878 \\
\hline \multirow[t]{6}{*}{ Region } & \multirow[t]{2}{*}{ East - South } & Age & -47 & 31.31 & $<0.0001$ \\
\hline & & Size & -4.2 & 26.11 & $<0.0001$ \\
\hline & \multirow[t]{2}{*}{ East - West } & Age & -18 & 4.347 & 0.0062 \\
\hline & & Size & -2.3 & 6.008 & 0.0015 \\
\hline & \multirow[t]{2}{*}{ South - West } & Age & 29 & 12.29 & $<0.0001$ \\
\hline & & Size & 1.9 & 4.728 & 0.0045 \\
\hline \multirow[t]{2}{*}{ Habitat } & \multirow[t]{2}{*}{ Beach - River } & Age & 3 & -0.2114 & 0.4533 \\
\hline & & Size & 0.6 & -0.044 & 0.3749 \\
\hline
\end{tabular}



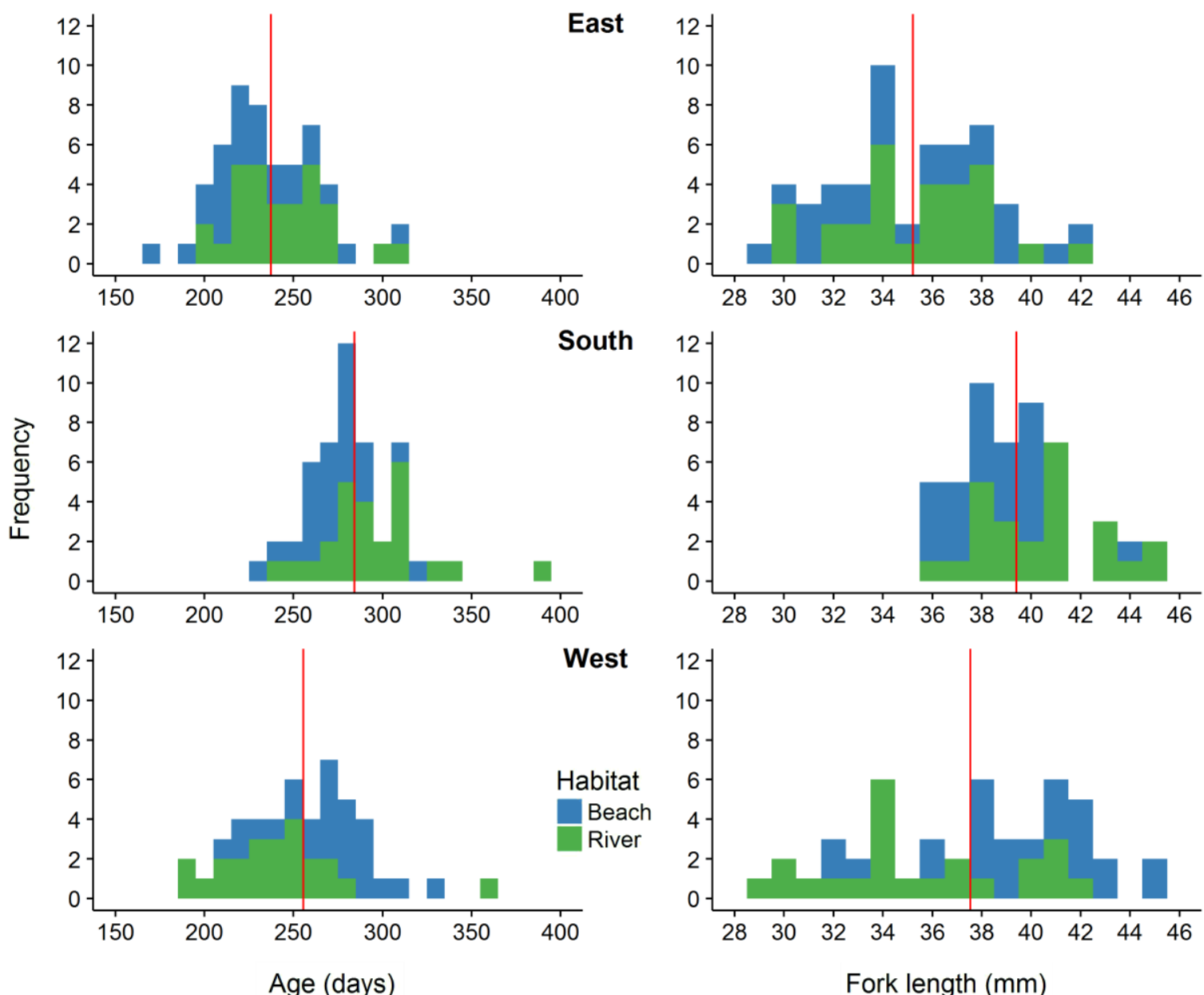

West

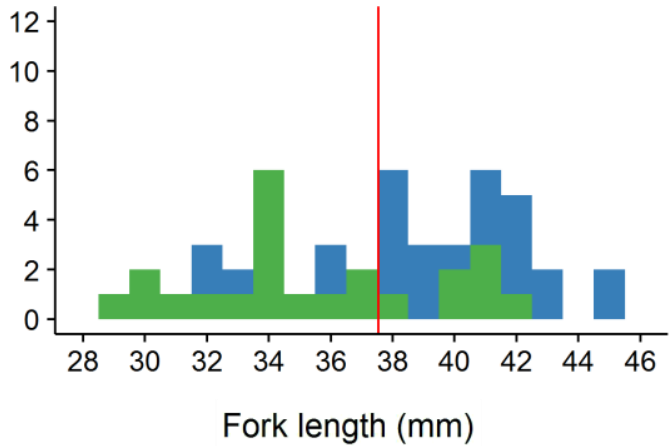

Figure 2.3. Histograms showing age and size of $R$. retropinna by region (east, south and west). Panels on the left show age frequencies (bar width $=10$ days) and panels on the right show fork length frequencies (bar width $=1 \mathrm{~mm}$ ). Vertical red lines show the mean. $R$. retropinna from beach and river habitat are stacked (not superimposed) in blue and green respectively.

\subsubsection{Relationship between age and size}

The linear model of fork length $\sim$ age provided a significant fit to the data $\left(\mathrm{F}_{1,199}=233.3\right.$, $p<0.0001)$, but a lot of variation remained unaccounted for $\left(\mathrm{R}^{2}=0.5396\right)$ (Table 2.3). However plotted residuals were not heteroscedastic, and the Breusch-Pagan test did not support heteroscedasticity over homoscedasticity $\left(\chi^{2} 1=1.2779, p=0.2583\right)$ implying that that the relationship between age and size was linear. 
Table 2.3. Results for the linear model fork length $\sim$ age. Results with $p<0.05$ are highlighted.

\begin{tabular}{lllll}
\hline \multirow{2}{*}{ Model fit } & $\mathbf{R}^{2}$ & Degrees of freedom & F-statistic & $\boldsymbol{p}$ value \\
\cline { 2 - 5 } & 0.5396 & 1,199 & 233.3 & $<0.0001$ \\
\hline Coefficient & Estimated value & Standard error & t-value & $\boldsymbol{p}$ value \\
\hline Intercept & 17.5174 & 1.2795 & 13.69 & $<0.0001$ \\
\hline Age & 0.0755 & 0.0049 & 15.27 & 0.0006 \\
\hline
\end{tabular}

\subsubsection{Morphological differences by region and habitat}

All measured morphological traits increased with age and length (Table 2.4, Table 2.5). In addition, all morphological traits varied among regions, with the exception of eye diameter when length was the covariate. Head length and body depth also varied among habitats (being greater for $R$. retropinna sampled from rivers), but only when age was the covariate. Age had an interactive effect with region on all morphological traits, and with habitat on body depth and eye diameter. Here, river these traits increased with age at a lower rate for river $R$. retropinna than for beach ones. Age also had a three-way interaction with region and habitat on body depth. Finally, length and region had an interactive effect on head length.

Pairwise interaction contrasts between regions (which I required to interpret the $>2$ levels of region) showed that the interaction between age and region at beach habitats was significantly different for head length between the east and the south (Table 2.6). Here, head length increased with age at a higher rate in the east. Between the south and the west, the interaction between age and region was significant for all morphological traits at beach habitat, and for both head length and eye diameter at river habitat. The interaction between length and region was also significant for head length. For each of these interaction contrasts, traits increased at a lower rate in the south.

Head length was the most variable morphological trait, while eye diameter was the least. Generally, the morphological traits of $R$. retropinna sampled from the south were larger than those from the west or east, but increased at lower rates. Morphological traits did not differ between the east and the west. Morphological traits tended to vary more for $R$. retropinna when age was used as covariate instead of length. 
Table 2.4. ANCOVA results for head length, body depth and eye diameter with age as covariate. Results with $p<0.05$ are highlighted.

\begin{tabular}{|c|c|c|c|c|c|c|c|c|c|c|c|c|c|}
\hline \multirow{2}{*}{ Covariate } & & \multicolumn{12}{|c|}{ Dependent variables } \\
\hline & & \multicolumn{4}{|c|}{ Head length } & \multicolumn{4}{|c|}{ Body depth } & \multicolumn{4}{|c|}{ Eye diameter } \\
\hline \multirow{15}{*}{ Age } & Model fit & $\begin{array}{l}\text { Adj. } \\
R^{2}\end{array}$ & df & $\begin{array}{l}\text { F- } \\
\text { stat }\end{array}$ & $p$ value & $\begin{array}{l}\text { Adj. } \\
R^{2}\end{array}$ & df & $\begin{array}{l}\text { F- } \\
\text { stat }\end{array}$ & $p$ value & $\begin{array}{l}\text { Adj. } \\
\mathbf{R}^{2}\end{array}$ & df & $\begin{array}{l}\text { F- } \\
\text { stat }\end{array}$ & $p$ value \\
\hline & & 0.6417 & 11,140 & 25.58 & $<0.0001$ & 0.5998 & 11,140 & 21.57 & $<0.0001$ & 0.6647 & 11,140 & 28.21 & $<0.0001$ \\
\hline & Coefficient & $\begin{array}{l}\text { Est. } \\
\text { value }\end{array}$ & $\begin{array}{l}\text { Std. } \\
\text { error }\end{array}$ & $\begin{array}{l}t \\
\text { value }\end{array}$ & $\begin{array}{l}p \\
\text { value }\end{array}$ & $\begin{array}{l}\text { Est. } \\
\text { value }\end{array}$ & $\begin{array}{l}\text { Std. } \\
\text { error }\end{array}$ & $\begin{array}{l}\text { t } \\
\text { value }\end{array}$ & $\begin{array}{l}p \\
\text { value }\end{array}$ & $\begin{array}{l}\text { Est. } \\
\text { value }\end{array}$ & $\begin{array}{l}\text { Std. } \\
\text { error }\end{array}$ & $\begin{array}{l}t \\
\text { value }\end{array}$ & $\begin{array}{l}p \\
\text { value }\end{array}$ \\
\hline & intercept & -0.655 & 1.0384 & -0.63 & 0.5290 & -1.508 & 0.6789 & -2.22 & 0.028 & -0.042 & 0.2391 & -0.18 & 0.8612 \\
\hline & age & 0.030 & 0.0045 & 6.71 & $<0.0001$ & 0.019 & 0.0029 & 6.36 & $<0.0001$ & 0.007 & 0.0010 & 7.06 & $<0.0001$ \\
\hline & regionSouth & 6.188 & 2.2312 & 2.77 & 0.0063 & 4.586 & 1.4589 & 3.14 & 0.0020 & 1.188 & 0.5138 & 2.31 & 0.0222 \\
\hline & regionWest & -0.254 & 1.6294 & -0.16 & 0.8763 & -0.406 & 1.0654 & -0.38 & 0.7040 & -0.270 & 0.3752 & -0.72 & 0.4734 \\
\hline & habitatRiver & 3.422 & 1.5844 & 2.16 & 0.0325 & 2.912 & 1.0359 & 2.81 & 0.0056 & 0.645 & 0.3649 & 1.77 & 0.0793 \\
\hline & age:regionSouth & -0.024 & 0.0085 & -2.83 & 0.0053 & -0.019 & 0.0056 & -3.49 & 0.0007 & -0.005 & 0.0020 & -2.37 & 0.0190 \\
\hline & age:regionWest & 0.002 & 0.0065 & 0.23 & 0.8208 & 0.001 & 0.0042 & 0.24 & 0.8078 & 0.001 & 0.0015 & 0.65 & 0.5178 \\
\hline & age:habitatRiver & -0.013 & 0.0066 & -1.97 & 0.0503 & -0.012 & 0.0043 & -2.78 & 0.0063 & -0.007 & 0.0015 & -1.72 & 0.0875 \\
\hline & $\begin{array}{l}\text { regionSouth: } \\
\text { habitatRiver }\end{array}$ & -3.689 & 2.8697 & -1.29 & 0.2007 & -4.004 & 1.8763 & -2.13 & 0.0346 & -0.384 & 0.6609 & -0.58 & 0.5621 \\
\hline & $\begin{array}{l}\text { regionWest: } \\
\text { habitatRiver }\end{array}$ & -2.417 & 2.2316 & -1.08 & 0.2806 & -2.035 & 1.4591 & -1.39 & 0.1654 & -0.285 & 0.5139 & -0.55 & 0.5806 \\
\hline & $\begin{array}{l}\text { age:regionSouth: } \\
\text { habitatRiver }\end{array}$ & 0.016 & 0.0108 & 1.52 & 0.1304 & 0.019 & 0.0071 & 2.62 & 0.0098 & 0.002 & 0.0025 & 0.81 & 0.4176 \\
\hline & $\begin{array}{l}\text { age:regionWest: } \\
\text { habitatRiver }\end{array}$ & 0.008 & 0.0090 & 0.84 & 0.4020 & 0.007 & 0.0059 & 1.20 & 0.2303 & 0.001 & 0.0021 & 0.44 & 0.6594 \\
\hline
\end{tabular}


Table 2.5. ANCOVA results for head length, body depth and eye diameter with length as covariate. Results with $p<0.05$ are highlighted.

\begin{tabular}{|c|c|c|c|c|c|c|c|c|c|c|c|c|c|}
\hline \multirow{2}{*}{ Covariate } & & \multicolumn{12}{|c|}{ Dependent variables } \\
\hline & & \multicolumn{4}{|c|}{ Head length } & \multicolumn{4}{|c|}{ Body depth } & \multicolumn{4}{|c|}{ Eye diameter } \\
\hline & \multirow{2}{*}{ Model fit } & Adj. $R^{2}$ & df & F-stat & $p$ value & Adj. $R^{2}$ & df & F-stat & $p$ value & Adj. $R^{2}$ & df & F-stat & $p$ value \\
\hline & & 0.9111 & 11,140 & 141.7 & $<0.0001$ & 0.7872 & 11,140 & 51.79 & $<0.0001$ & 0.850 & 11,140 & 78.81 & $<0.0001$ \\
\hline & Coefficient & $\begin{array}{l}\text { Est. } \\
\text { value }\end{array}$ & $\begin{array}{l}\text { Std. } \\
\text { error }\end{array}$ & $\begin{array}{l}\text { t } \\
\text { value }\end{array}$ & $\begin{array}{l}p \\
\text { value }\end{array}$ & $\begin{array}{l}\text { Est. } \\
\text { value }\end{array}$ & $\begin{array}{l}\text { Std. } \\
\text { error }\end{array}$ & $\begin{array}{l}t \\
\text { value }\end{array}$ & $\begin{array}{l}p \\
\text { value }\end{array}$ & $\begin{array}{l}\text { Est. } \\
\text { value }\end{array}$ & $\begin{array}{l}\text { Std. } \\
\text { error }\end{array}$ & $\begin{array}{l}\text { t } \\
\text { value }\end{array}$ & $\begin{array}{l}p \\
\text { value }\end{array}$ \\
\hline & intercept & -3.624 & 0.6862 & -5.28 & $<0.0001$ & -2.847 & 0.6569 & -4.33 & $<0.0001$ & -0.606 & 0.2122 & -2.85 & 0.0050 \\
\hline & length & 0.282 & 0.0195 & 14.46 & $<0.0001$ & 0.160 & 0.0186 & 8.60 & $<0.0001$ & 0.064 & 0.0060 & 10.59 & $<0.0001$ \\
\hline & regionSouth & 3.944 & 1.6355 & 2.41 & 0.0172 & 0.760 & 1.5655 & 0.49 & 0.6281 & 0.689 & 0.5058 & 1.36 & 0.1754 \\
\hline & regionWest & -0.996 & 0.9990 & -1.00 & 0.3206 & -0.777 & 0.9563 & -0.81 & 0.4179 & -0.441 & 0.3089 & -1.43 & 0.1556 \\
\hline & habitatRiver & -0.01 & 1.0295 & -0.09 & 0.9306 & -0.009 & 0.9854 & -0.01 & 0.9928 & -0.01 & 0.3184 & -0.03 & 0.9779 \\
\hline \multirow[t]{7}{*}{ Length } & lgth:regionSouth & -0.103 & 0.0433 & -2.39 & 0.0183 & -0.031 & 0.0414 & -0.75 & 0.4539 & -0.017 & 0.0134 & -1.30 & 0.1960 \\
\hline & lgth:regionWest & 0.027 & 0.0267 & 1.00 & 0.3180 & 0.017 & 0.0256 & 0.65 & 0.5139 & 0.011 & 0.0083 & 1.32 & 0.1894 \\
\hline & lgth:habitatRiver & 0.019 & 0.0291 & 0.64 & 0.5201 & 0.006 & 0.0279 & 0.21 & 0.8362 & 0.007 & 0.0090 & 0.30 & 0.7618 \\
\hline & $\begin{array}{l}\text { regionSouth: } \\
\text { habitatRiver }\end{array}$ & -2.473 & 2.1433 & -1.15 & 0.2505 & -1.159 & 2.0517 & -0.56 & 0.5732 & -0.114 & 0.6628 & -0.17 & 0.8642 \\
\hline & $\begin{array}{l}\text { regionWest: } \\
\text { habitatRiver }\end{array}$ & 0.828 & 1.4152 & 0.59 & 0.5595 & 1.202 & 1.3547 & 0.89 & 0.3767 & 0.203 & 0.4377 & 0.46 & 0.6435 \\
\hline & $\begin{array}{l}\text { lgth:regionSouth: } \\
\text { habitatRiver }\end{array}$ & 0.057 & 0.0562 & 1.01 & 0.3129 & 0.037 & 0.0538 & 0.68 & 0.4982 & 0.002 & 0.0174 & 0.08 & 0.9330 \\
\hline & $\begin{array}{l}\text { lgth:regionWest: } \\
\text { habitatRiver }\end{array}$ & -0.038 & 0.0389 & -0.98 & 0.3266 & -0.043 & 0.0372 & -1.17 & 0.2450 & -0.01 & 0.0120 & -0.63 & 0.5293 \\
\hline
\end{tabular}


Table 2.6. Post hoc results from ANCOVA models in Table 2.4 and Table 2.5, giving the pairwise interaction contrasts between regions. There are separate interaction contrasts for each habitat. Results with $p<0.05$ are highlighted.

\begin{tabular}{|c|c|c|c|c|c|c|c|c|c|c|c|c|c|c|}
\hline \multirow[b]{3}{*}{ Covariate } & \multirow[b]{3}{*}{$\begin{array}{l}\text { Region } \\
\text { comparison }\end{array}$} & \multirow[b]{3}{*}{ Habitat } & \multicolumn{12}{|c|}{ Dependent variables } \\
\hline & & & \multicolumn{4}{|c|}{ Head length } & \multicolumn{4}{|c|}{ Body depth } & \multicolumn{4}{|c|}{ Eye diameter } \\
\hline & & & $\begin{array}{l}\text { Difference in } \\
\text { est. value }\end{array}$ & df & $\begin{array}{l}\text { F- } \\
\text { stat }\end{array}$ & $\begin{array}{l}p \\
\text { value }\end{array}$ & $\begin{array}{l}\text { Difference in } \\
\text { est. value }\end{array}$ & df & $\begin{array}{l}\text { F- } \\
\text { stat }\end{array}$ & $\begin{array}{l}p \\
\text { value }\end{array}$ & $\begin{array}{l}\text { Difference in } \\
\text { est. value }\end{array}$ & df & $\begin{array}{l}\text { F- } \\
\text { stat }\end{array}$ & $\begin{array}{l}p \\
\text { value }\end{array}$ \\
\hline \multirow{6}{*}{ Age } & \multirow{2}{*}{ East-South } & Beach & 0.0240505 & 1 & 8.02 & 0.0266 & 0.0193690 & 1 & 12.16 & 0.0033 & 0.0046419 & 1 & 5.63 & 0.0761 \\
\hline & & River & 0.0076108 & 1 & 1.30 & 0.5130 & 0.0008582 & 1 & 0.04 & 1.0000 & 0.0026186 & 1 & 2.90 & 0.2728 \\
\hline & \multirow{2}{*}{ East-West } & Beach & -0.0014653 & 1 & 0.05 & 0.8208 & -0.0010290 & 1 & 0.06 & 1.0000 & -0.0009639 & 1 & 0.42 & 0.5178 \\
\hline & & River & -0.0090087 & 1 & 2.09 & 0.4517 & -0.0080976 & 1 & 3.95 & 0.1466 & -0.0018768 & 1 & 1.71 & 0.3863 \\
\hline & \multirow{2}{*}{ South-West } & Beach & -0.0255157 & 1 & 8.82 & 0.0211 & -0.0203980 & 1 & 13.18 & 0.0024 & -0.0056058 & 1 & 8.02 & 0.0265 \\
\hline & & River & -0.0166195 & 1 & 7.75 & 0.0266 & -0.0089558 & 1 & 5.27 & 0.0930 & -0.0044953 & 1 & 10.69 & 0.0081 \\
\hline \multirow{6}{*}{ Length } & \multirow{2}{*}{ East-South } & Beach & 0.103343 & 1 & 5.70 & 0.0913 & 0.031107 & 1 & 0.56 & 1.0000 & 0.0173856 & 1 & 1.69 & 0.6099 \\
\hline & & River & 0.046466 & 1 & 1.69 & 0.7853 & -0.005399 & 1 & 0.02 & 1.0000 & 0.0159237 & 1 & 2.07 & 0.6099 \\
\hline & \multirow{2}{*}{ East-West } & Beach & -0.026808 & 1 & 1.00 & 0.9036 & -0.016756 & 1 & 0.43 & 1.0000 & -0.0109090 & 1 & 1.74 & 0.6099 \\
\hline & & River & 0.011464 & 1 & 0.17 & 0.9036 & 0.026692 & 1 & 0.98 & 1.0000 & -0.0033268 & 1 & 0.15 & 0.7036 \\
\hline & \multirow{2}{*}{ South-West } & Beach & -0.130151 & 1 & 9.25 & 0.0168 & -0.047863 & 1 & 1.37 & 1.0000 & -0.0282945 & 1 & 4.57 & 0.2052 \\
\hline & & River & -0.035002 & 1 & 1.08 & 0.9036 & 0.032091 & 1 & 0.99 & 1.0000 & -0.0192504 & 1 & 3.41 & 0.3354 \\
\hline
\end{tabular}




\subsubsection{Otolith growth rate differences by age, hatch date and region}

Otolith size-at-age increased when age increased and when hatch date increased (i.e. as the hatching season progressed), but did not vary according to region (Table 2.7). Age and hatch date both interacted with region differently between east and south, and between south and west. This suggests that otolith size-at-age for older and later-hatching $R$. retropinna from the south was less than that for ones from the east and west. Age and hatch date interacted negatively to estimate otolith size-atage, suggesting that otolith size-at-age for older $R$. retropinna would be less for latehatching individuals than it would be for early-hatching individuals. Finally, age, hatch date and region interacted differently for the south than they did for the east or the west. This makes the earlier interaction between age and hatch date difficult to interpret, but it may suggest that it had more of an effect on otolith size-at-age for $R$. retropinna in the east and west than it did for ones from the south.

The random effect for individual fish gave the variability around the intercept (i.e. around the otolith size-at-age averaged across all individuals [Table 2.7]). This variability was similar in magnitude to the residual error in the model, which suggests that differences between individual fish provide roughly half of the variation in the model that is not accounted for by fixed effects. The random effect also gave the variability around the slope (i.e. around the average slope-effect of age on otolith size-at-age), and the correlation of the intercept with the slope. The correlation was negative, suggesting that an individual $R$. retropinna with a nonaverage (i.e. more standard deviations) otolith size-at-age intercept would still have an average (i.e. fewer standard deviations) slope-effect for age. This may be an indication that variations in otolith size do not tend to 'snowball' as an individual $R$. retropinna grows - rather they tend to return towards a population-level average. 
Table 2.7. Table showing the estimated coefficients for Model 2.1 (for both fixed and random effects). For the fixed effects, the estimated value, standard error, degrees of freedom, $t$-value and $p$ value are given. The estimated values for 'age', 'hatch date' and each interaction are slopes. In this model the coefficient for the first level of each categorical variable (i.e. east for 'region' and beach for 'habitat') is set at the level of the intercept, and the coefficients of the other levels are given in relation to it (i.e. in terms of their distance from the intercept). For any interactions containing these categorical variables, the coefficient for the first level of the variable (i.e. its slope) is set to zero. To show direct comparisons between the second and third levels of region (i.e. south and west) and their interactions, I include coefficients from another version of the same model, where south was set as the intercept instead of east. The standard deviation for the intercept and slope of the random effect are given, as well as the correlation between the intercept and the slope for age. Results with $p<0.05$ are highlighted.

\begin{tabular}{|c|c|c|c|c|c|}
\hline $\begin{array}{l}\text { Coefficient (fixed, } \\
\text { intercept at regionEast) }\end{array}$ & $\begin{array}{l}\text { Estimated } \\
\text { value }\end{array}$ & $\begin{array}{l}\text { Standard } \\
\text { error }\end{array}$ & df & t-value & $p$ value \\
\hline intercept & -12.7206 & 2.7421 & 15042 & -4.639 & $<0.0001$ \\
\hline age & 1.8386 & 0.1292 & 15042 & 14.236 & $<0.0001$ \\
\hline hatch date & 0.0665 & 0.0166 & 146 & 4.007 & 0.0001 \\
\hline regionSouth & 5.1268 & 3.5059 & 146 & 1.462 & 0.1458 \\
\hline regionWest & -0.7349 & 3.4727 & 146 & -0.212 & 0.8327 \\
\hline age:hatch date & -0.0046 & 0.0008 & 15042 & -5.842 & $<0.0001$ \\
\hline age:regionSouth & -0.6308 & 0.1651 & 15042 & -3.820 & 0.0001 \\
\hline age:regionWest & -0.0419 & 0.1636 & 15042 & -0.256 & 0.7980 \\
\hline hatch date:regionSouth & -0.0518 & 0.0245 & 146 & -2.112 & 0.0364 \\
\hline hatch date:regionWest & 0.0094 & 0.0219 & 146 & 0.428 & 0.6695 \\
\hline $\begin{array}{l}\text { age:hatch date: } \\
\text { regionSouth }\end{array}$ & 0.0048 & 0.0012 & 15042 & 4.135 & $<0.0001$ \\
\hline $\begin{array}{l}\text { age:hatch date: } \\
\text { regionWest }\end{array}$ & 0.0000 & 0.0010 & 15042 & 0.017 & 0.9864 \\
\hline $\begin{array}{l}\text { Coefficient (fixed, } \\
\text { intercept at regionSouth) }\end{array}$ & $\begin{array}{l}\text { Estimated } \\
\text { value }\end{array}$ & $\begin{array}{l}\text { Standard } \\
\text { error }\end{array}$ & df & t-value & $p$ value \\
\hline regionWest & -5.8617 & 3.0517 & 146 & -1.921 & 0.0567 \\
\hline age:regionWest & 0.5889 & 0.1437 & 15042 & 4.097 & $<0.0001$ \\
\hline hatch date:regionWest & 0.0612 & 0.0230 & 146 & 2.659 & 0.0087 \\
\hline $\begin{array}{l}\text { age:hatch date: } \\
\text { regionWest }\end{array}$ & -0.0048 & 0.0011 & 15042 & -4.394 & $<0.0001$ \\
\hline
\end{tabular}

\begin{tabular}{lll}
\hline Coefficient (random) & Standard deviation & Correlation \\
\hline intercept & 3.3527 & \\
\hline age & 0.1611 & -0.565 \\
\hline residual & 3.6044 & \\
\hline
\end{tabular}




\subsection{Discussion}

I found several patterns of demographic heterogeneity in Lake Taupo. $R$. retropinna sampled from the southern region of Lake Taupo differed significantly to those from the east and west. The $R$. retropinna I sampled from the south were older (implying that they had hatched earlier) and were larger. All morphological features were roughly proportionally to each other across all regions and habitats, suggesting that no marked variation in morphological proportions exists for $R$. retropinna in Lake Taupo.

The morphological traits of southern $R$. retropinna increased with age and with size at a slightly slower rate than ones sampled from the east and west, and their otolith growth rates were less affected by age and hatch date. It is difficult to see a clear interpretation for these results. Although I found no statistical evidence for heteroscedasticity, it is likely (as with most fish species) the relationship between age and length is fundamentally non-isometric for $R$. retropinna. It is also possible that non-isometric growth partly drove my morphological trait comparisons. While it is still possible that low-magnitude differences in morphological traits exist between regions and/or habitats, the differences in size and age are clearer and easier to interpret. This regional size and age structure for adult populations will likely have impacts for the fecundity of $R$. retropinna at different sites and impact on their recruitment dynamics (Scott et al. 2006).

What might potentially drive these differences in size and age between regions? Jolly (1967) and Stephens (1984) both noticed similar regional differences in size. Jolly hypothesised that planktonic larvae would tend to aggregate near the eastern and north-eastern beaches due to the prevailing wind direction (from the west to south-west) and currents within the lake tending north towards the head of the Waikato River. Once fish reached what she termed 'shoaling size' ( $>27 \mathrm{~mm}$ fork length and vulnerable to beach seines) they would generally recruit to the nearest shore habitat, which lies on the eastern and north-eastern beaches of Lake Taupo. Then as they grew older/larger, individuals would make their way to the upwind/up-current shores of the lake in the south and west. My results support 
Jolly's hypothesis, as show no evidence that varying growth rates drive demographic heterogeneity in the Lake Taupo $R$. retropinna population.

Stephens observed that the different regions of Lake Taupo provide $R$. retropinna with differing quantities of littoral habitat for feeding and/or spawning (i.e. while the coast in west and south-west is a mixture of sheer cliffs and shallow bays, the east is predominantly sandy beach providing lots of littoral habitat). From this, he suggested that $R$. retropinna in the west are compelled to shoal at high densities due to the relative lack of littoral habitat, and that this incurs a higher rate of predation from salmonids. Density dependent salmonid predation is likely to be an important driver of demographic heterogeneity on littoral shoals $R$. retropinna - directly via selection pressure as well as indirectly (e.g. via induced behavioural prey responses). Assuming that smaller $R$. retropinna are more vulnerable to salmonid predation This hypothesis provides an additional possible explanation for why the $R$. retropinna I sampled in the south were older and larger than in the east. It could also explain the unusual finding where beach $R$. retropinna in the west were old and large, but river ones were young and small - perhaps the smaller $R$. retropinna were seeking extra shelter from salmonid predators. 


\section{CHAPTER 3: INDIVIDUAL VARIATION BETWEEN TWO POPULATIONS}

\subsection{Introduction and aims}

\subsubsection{Seasonality, morphs, and individual variation}

In the previous chapter, I observed that $R$. retropinna with an earlier hatch date had significantly slower rates of otolith growth than ones with later hatch dates. Phenology is often driven by seasonal effects (Visser \& Both 2005). In this chapter I look for patterns in individual variation between samples taken from two $R$. retropinna populations (Lake Taupo and Wellington Harbour), each of which is subject to different seasonal effects. Additionally, one of these $R$. retropinna populations is landlocked (Lake Taupo) while the other is sea-going (Wellington Harbour). Landlocked and sea-going populations conform to different 'morphs' (McDowall 1979; Northcote \& Ward 1985; Ward et al. 1989; Ward et al. 2005; Tana \& Tempero 2013). This makes it more difficult to interpret patterns of individual variation (i.e. are they due to nature, or nurture?).

\subsubsection{Aims}

I asked the following questions using $R$. retropinna from Lake Taupo and Wellington Harbour to explore individual variation between populations in environmentally distinct systems. 1) Do $R$. retropinna from each system share common hatching and recruitment phenologies? 2) Does length or morphology covary differently with age between systems? Do larval otolith growth rates vary between systems? 3) How do water temperature and chlorophyll a levels (two important variables for fish growth) differ between the systems from season to season? 4) Do water temperature and chlorophyll a predict otolith increment widths differently between systems? 


\subsection{Methods}

\subsubsection{Study area and sampling}

Lake Taupo is a large and deep oligotrophic lake (surface area $616 \mathrm{~km}^{2}$, average depth $110 \mathrm{~m}$ ) which stratifies from spring to autumn, but is well mixed during winter (Vincent et al. 1983; Verburg \& Albert 2016). Its population of $R$. retropinna receives no immigration from other populations and conforms to a landlocked 'morph' (Jolly 1967; McDowall 1979; Stephens 1984). In contrast, Wellington Harbour is smaller and shallower $\left(89 \mathrm{~km}^{2}\right.$, mostly $<20 \mathrm{~m}$ deep), is more eutrophic and is well mixed all year around (Booth 1975). Its $R$. retropinna population has not been the subject of scientific study before, but is likely typical of other sea-going populations (McDowall 1990; Ward et al. 2005).

I sampled juvenile and adult $R$. retropinna from a landlocked population using beach seines in Lake Taupo. For more information, see my methods for chapter 2 .

I sampled juvenile and adult $R$. retropinna from a sea-going population in the Hutt River on four occasions (Table 3.1, Figure 3.1). I received them as by-catch over a from two separate sampling efforts targeting whitebait/inanga, Galaxias maculatus (see acknowledgments). On the first two occasions (in October and November 2015) I sampled with A-frame nets of the kind used by whitebait fishers $(0.65 \times 1.2 \mathrm{~m}$ aperture and $0.9 \mathrm{~m}$ depth, with $2 \mathrm{~mm}$ mesh). I set the nets in the shallows approximately $250 \mathrm{~m}$ upstream of the river mouth. Here, I sampled from an initial year-cohort of juvenile $R$. retropinna which had hatched from late 2014 to early 2015 as they migrated upstream from Wellington Harbour (I termed these ' 1 st juveniles', $\mathrm{n}=22)$.

On the third and fourth occasions (in April and June 2016) I sampled from the river bank at Sladden Park, approximately 1500m upstream of the river mouth (Table 3.1, Figure 3.1). Here, I used sock nets $(0.75 \times 1.13 \mathrm{~m}$ aperture and $2.2 \mathrm{~m}$ depth, with $3 \mathrm{~mm}$ mesh), as they performed better in the deeper water. I sampled adult $R$. retropinna from the same year-cohort as previously (I termed these ' 1 st adults', $n=6$ ). These had likely resided in the river since their migration the year before (McDowall 1990). I also sampled some juveniles from a second year-cohort which had hatched in early 
2016 (' $2^{\text {nd }}$ juveniles', $n=3$ ). Presumably, these had recently completed their migration from Wellington Harbour. On all sampling occasions, I set the nets two hours before high tide and checked them approximately every 30 minutes for four hours.

Table 3.1. Wellington Harbour samples. Given for each sampling occasion as the cohorts present, locality, UTM coordinates, date of sampling and number of fish included in data analysis.

\begin{tabular}{llllll}
\hline $\begin{array}{l}\text { Sampling } \\
\text { occasion }\end{array}$ & Cohorts present & Locality & $\begin{array}{l}\text { Latitude, } \\
\text { longitude }\end{array}$ & $\begin{array}{l}\text { Date of } \\
\text { sampling }\end{array}$ & n \\
\hline $\mathbf{1}$ & $1^{\text {st juveniles }}$ & $\begin{array}{l}\text { Hutt River } \\
\text { mouth }\end{array}$ & $\begin{array}{l}-41.238288, \\
174.901072\end{array}$ & $\begin{array}{l}28 \text { th Oct } \\
2015\end{array}$ & 10 \\
& & Hutt River & -41.238288, & 18 th Nov & 12 \\
\hline $\mathbf{2}$ & $1^{\text {st juveniles }}$ & mouth & 174.901072 & 2015 & \\
\hline $\mathbf{3}$ & & Sladden Park & -41.225155, & 13 th Apr & 4 \\
& $1^{\text {st } \text { adults }}$ & & 174.898443 & 2016 & \\
\hline $\mathbf{4}$ & & Sladden Park & -41.225155, & 4 th Jun 2016 & 5 \\
& $1^{\text {st } \text { adults, }}$ & & 174.898443 & & \\
\hline
\end{tabular}




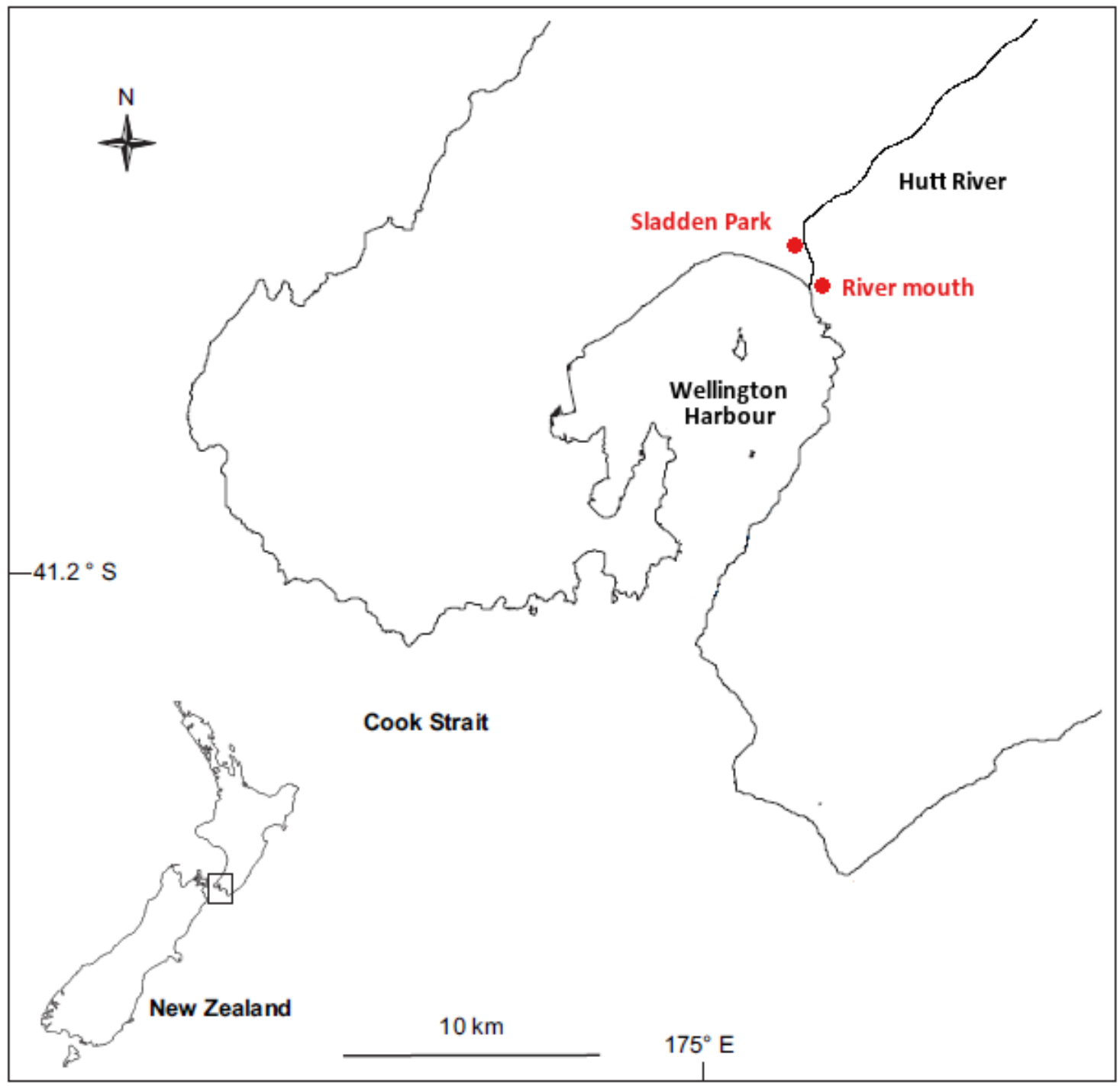

Figure 3.1. Map of Wellington Harbour (adapted from Helson et al. 2007). Shown in red are the Wellington sampling locations.

\subsubsection{Body measurements}

To estimate differences in overall body size between Lake Taupo and Wellington Harbour, I measured fork length. To estimate patterns of variation in morphological traits, I measured head length and body depth (possibly indicative of fusiform shape [Vogel 1994; Langerhans \& Reznick 2010]) and eye diameter (possibly indicative of visual acuity [Pankhurst \& Montgomery 1994]). I evaluated this morphological variation in relation to body size or age. For more information, see my methods in chapter 2. 


\subsubsection{Otolith preparation and daily increments}

See chapter 2 for information about my otolith preparation and daily increment measurements.

\subsubsection{Hatching phenology and recruitment age}

To examine whether $R$. retropinna hatch phenology differed between Lake Taupo and Wellington Harbour, I used a K-sample Anderson-Darling test (Scholz \& Zhu 2016), which determines whether two samples may be modelled as having come from a common distribution (Anderson \& Darling 1954). I compared the hatch dates of juvenile and adult $R$. retropinna from the 2014-2015 season of Lake Taupo $(n=201)$ with those of Wellington Harbour ( $1^{\text {st }}$ juveniles and $1^{\text {st }}$ adults, $\left.n=28\right)$. I excluded the three Wellington $R$. retropinna from the 2015-2016 hatching season ( $2^{\text {nd }}$ juveniles) from this test.

I defined the age recruitment to be when $R$. retropinna cease living pelagically and move to a river, estuary, or the shore. I assumed that $R$. retropinna in Wellington Harbour would move upstream beyond the sampling point upon recruiting, and that the '1st juveniles' year-cohort would be a representative sample for these individuals. However my sampling design in Lake Taupo was unable to discriminate between recently recruited juveniles, and more distantly recruited adults - as they share the same habitats and shoal together. Therefore I followed Jolly (1967) and Stephens (1984) in assuming that all Lake Taupo $R$. retropinna recruit to the shoreline once they have grown to approximately $30 \mathrm{~mm}$ fork length, and considered individuals $\leq 32 \mathrm{~mm}$ to be recent recruits (I raised this slightly from $30 \mathrm{~mm}$ in order to obtain a testable sample size). I used a $K$-sample AndersonDarling test to compare the ages of recent recruits from Lake Taupo $(n=22)$ with those from Wellington Harbour $(n=22)$.

\subsubsection{Length and morphology covarying with age}

To see whether the relationship between length and age was linear for Wellington Harbour $R$. retropinna, I evaluated a general linear model that predicted fork length as a function of age. As for Lake Taupo R. retropinna (see chapter 2), I evaluated the residuals for this relationship using plots and a Breusch-Pagan test (Breusch \& 
Pagan 1979; Zeileis \& Hothorn 2002). I interpreted homoscedastic residuals as evidence for a linear relationship between length and age.

I used general linear models to evaluate variation in morphological traits of $R$. retropinna between samples from Lake Taupo and Wellington Harbour. To control for variation in fish age, I used an analysis of covariance (ANCOVA) with age (days since hatching) as a covariate. This model assumes a linear relationship between age and trait size. In four separate tests, I evaluated size (fork length) and morphology (head length, body depth and eye diameter).

\subsubsection{Otolith growth rate differences}

I evaluated variation in growth rates of landlocked and marine $R$. retropinna (reconstructed from otoliths) as a function of age and system (i.e. Lake Taupo vs Wellington Harbour). To do this, I modelled the otolith size-at-age (i.e., radius at a given daily increment) using a general linear mixed effects model from Pinheiro (2016) with restricted maximum likelihood estimation (Model 3.1). See methods in chapter 2 for a description of mixed effects models.

For Wellington Harbour $R$. retropinna ( $\mathrm{n}=31)$, I only wanted to include days accrued as juveniles in the marine environment (as opposed to adults in a freshwater environment), so I truncated my Wellington dataset to the first 172 days of otolith growth (the age of the youngest individual sampled minus one). In order to compare otolith growth rates across strictly the same range of ages, I applied the same truncation to my Taupo dataset $(n=201)$.

\section{Model 3.1}

$$
\text { radius } \sim \text { age } * \text { system }+(1+\text { age } \mid \text { sample } / \text { fish })+\text { error }
$$

For Model 3.1, the dependent variable 'radius' is the distance of each daily increment from the centre of the otolith in $\mu \mathrm{m}$ (i.e. otolith size-at-age), for each $R$. retropinna. The model includes 'age' (a covariate, modelled as a fixed effect) associated with each observation and 'region' (fixed effect with two levels: Taupo and Wellington). These fixed effects were crossed, so the model also included a twoway interaction between age and region. 
I also include a random effect ' $1+$ age|sample/fish' as a variable to account for 'individual fish' (i.e., each fish had 100 consecutive daily observations of otolith sizeat-age). This meant the model gave each individual fish a random intercept and slope for the dependent variable 'radius'. The slope allowed each individual fish to interact uniquely with each level of 'age', which avoids the assumption that each repeated measure of 'age' is independent from the others. Including the slope also allowed the model to include the complete size-at-age record for each individual, as opposed to using averaged growth rates for individuals (Weisberg et al. 2010). Finally, 'Individual fish' was nested within 'sample'. This meant that model assigned another random intercept and slope to each $R$. retropinna according to its sample (see Table 2.1 and Table 3.1). This guarded against possible non-independence between fish from the same sample.

\subsubsection{Temperature and chlorophyll a data}

In order to characterise the environmental growth conditions for $R$. retropinna in Lake Taupo and Wellington Harbour, I estimated water temperature $\left({ }^{\circ} \mathrm{C}\right)$ and chlorophyll a levels $\left(\mathrm{mg} / \mathrm{m}^{3}\right)$, using published environmental data. Wherever possible, I used data collected over the period where my $R$. retropinna samples lived in both systems (October 2014 - November 2015).

For Lake Taupo, I used data from Verburg \& Albert (2016), who measured temperature and chlorophyll a at $10 \mathrm{~m}$ depth at 2-3 weekly intervals. Although these data come from a single point near the middle of Lake Taupo, they are highly representative of the entire lake (Verburg \& Albert 2016). Data from after the $27^{\text {th }}$ of August 2015 were unavailable at the time of writing, so here I used data for September - November from 2012, 2013 and 2014.

For temperature data from Wellington Harbour, I took daily averages from measurements taken every 15 minutes by the Greater Wellington Regional Council at Queen's Wharf. For chlorophyll a data, the best available source was Helson et al. (2007), who published seasonal averages (Sept-Nov, Dec-Feb, Mar-May, Jun-Aug) for 1998-1999 at three sites within the harbour (Point Dorset, Kau Bay and Eastbourne). Averaging over sites, I used chlorophyll a levels from the midpoint of each season to provide data from July 2014 to January 2016. 


\section{Model 3.2}

env. variable $\sim \sin \left(\frac{2 \pi \text { date }}{365}\right)+\cos \left(\frac{2 \pi \text { date }}{365}\right)+\sin \left(\frac{4 \pi \text { date }}{365}\right)+\cos \left(\frac{4 \pi \text { date }}{365}\right)+$ error

I fitted four sinusoidal least squares regression models to the data (each a version of Model 3.2), one for each environmental variable (temperature, chlorophyll a) at each system (Lake Taupo, Wellington Harbour). These models use harmonics (i.e. the pairs of sine and cosine terms) to predict the environmental variable. The period for the first harmonic is one year $(2 \pi / 365)$, the second is two years $(4 \pi / 365)$, the third three years $(6 \pi / 365)$, etc. Increasing the number of harmonics will improve the model's fit, but too many will result in overfitting. To guard against overfitting, I refrained from adding harmonics if it resulted in only a small or a negative change in the adjusted $\mathrm{R}^{2}$ value. I also visually checked the predicted values against the real ones to make sure they formed an even and smooth sinusoidal curve. In practice, a greater number of real data points permitted a greater number of harmonics. For temperature and chlorophyll a from Lake Taupo (moderate numbers of data points) I fitted two harmonics, while for temperature in Wellington Harbour (a great number of data points) I fitted three. For chlorophyll a from Wellington Harbour (just seven data points) I fitted only one harmonic.

For each of these models, I obtained predicted values of the environmental variable for the period where my R. retropinna samples lived (October 2014 - November 2015). I added these to my otolith increment data, obtaining estimates of ambient water temperature and chlorophyll a levels for each day in each individual's growth history.

\subsubsection{Increment width comparison}

Increment width-at-age models (for example Goodwin et al. [2003]) are an alternative to size-at-age models. I evaluated how intrinsic and extrinsic factors related to variation in increment widths for landlocked and marine $R$. retropinna (reconstructed from otoliths). To do this, I modelled otolith increment width-at-age (i.e., the width of a given daily increment) for samples from Lake Taupo and Wellington Harbour using a general linear mixed effects model from Pinheiro 
(2016) with restricted maximum likelihood estimation (Model 3.3). See methods in chapter 2 for a description of mixed effects models.

For this analysis, I used all the otolith growth histories from Lake Taupo $R$. retropinna samples (i.e. up until the $8^{\text {th }}$ of November 2015) but I truncated growth histories for adult Wellington Harbour R. retropinna samples to the time when I sampled their year-cohort at the juvenile stage (which was up until the $18^{\text {th }}$ of November 2015). I assumed that the majority of my $R$. retropinna samples from the Hutt River had spent most of their larval development within Wellington Harbour (under the environmental conditions explained in the previous section).

\section{Model 3.3}

width $\sim$ system $*$ age $*$ time $*$ temperature $*$ chl. $a+$ age $\mid$ site $/$ fish + error

For Model 3.3, the dependent variable 'width' is the width of each daily increment in $\mu \mathrm{m}$ (i.e. otolith width-at-age), for each R. retropinna. The model includes five fixed effects, the first being 'system' (a categorical variable specifying the system for each individual). The next four fixed effects are associated with every observation of 'width'. These are 'age' (a covariate), 'time' (another covariate, representing the calendar date for each day of life for R. retropinna; these ranged from October 2014 - November 2015 and were coded as sequential numbers), 'temperature' and 'chlorophyll a' (estimates of sinusoidal environmental variables, taken from Model 3.2). These fixed effects were crossed, so the model included two, three and fourway interactions between these variables. The random effects are the same as for Model 3.1.

\subsection{Results}

\subsubsection{Otolith characteristics}

I observed differences in $R$. retropinna otolith microstructure between samples from Lake Taupo and Wellington Harbour. Otoliths from Lake Taupo samples had an initial period of rapid growth (increments $1.5-2.5 \mu \mathrm{m}$ wide), which ceased after approximately 60-100 days of growth. Then came a period of narrow increments $(0.5-1.25 \mu \mathrm{m})$ interspersed with 'bleached bands' (areas of 5-20 increments where 
the otolith became translucent and the increments were particularly narrow and faint). All otoliths sampled from Lake Taupo contained at least one bleached band, which may indicate periods of physiological stress (Tzeng \& Yu 1992). Bleached bands and the period of narrow increments generally occurred during the winter months. Increments remained narrow until the final 40-60 days of growth, when they gradually returned to their original size. Otoliths from the Wellington samples were larger with more broad and regular daily increments, and did not contain any bleached bands.

\subsubsection{Hatching phenology and recruitment age}

Estimated hatch dates for $R$. retropinna sampled from Lake Taupo ranged from the $17^{\text {th }}$ of October 2014 to the $17^{\text {th }}$ of May 2015, with a mean on the $22^{\text {nd }}$ of February 2015 (Table 3.2, Figure 3.2). This was close to the hatching season for Wellington Harbour, which ranged from the $2^{\text {nd }}$ of December 2015 to the $18^{\text {th }}$ of May 2015 $\left(\right.$ mean $=3^{\text {rd }}$ of March). Note that the 25-day difference in mean hatch date between Taupo and Wellington is less than some differences within Lake Taupo (where there was a 28-day difference between its eastern and western geographic regions - see chapter 2).

In Lake Taupo, estimated recruitment ages for $R$. retropinna ranged from 172 to 252 days old $($ mean $=213$ ), while in Wellington Harbour they ranged from 173 to 351 days $($ mean $=223)$.

Table 3.2. Results of Anderson Darling test for differences in hatch date and recruitment age between Lake Taupo and Wellington Harbour.

\begin{tabular}{llll}
\hline $\begin{array}{l}\text { Comparison } \\
\text { between Taupo } \\
\text { and Wellington }\end{array}$ & Difference & T.AD & $\boldsymbol{p}$ value \\
\hline Hatch date & -25 days & 8.780 & 0.0002 \\
Recruitment age & -10 days & -0.3418 & 0.5261 \\
\hline
\end{tabular}



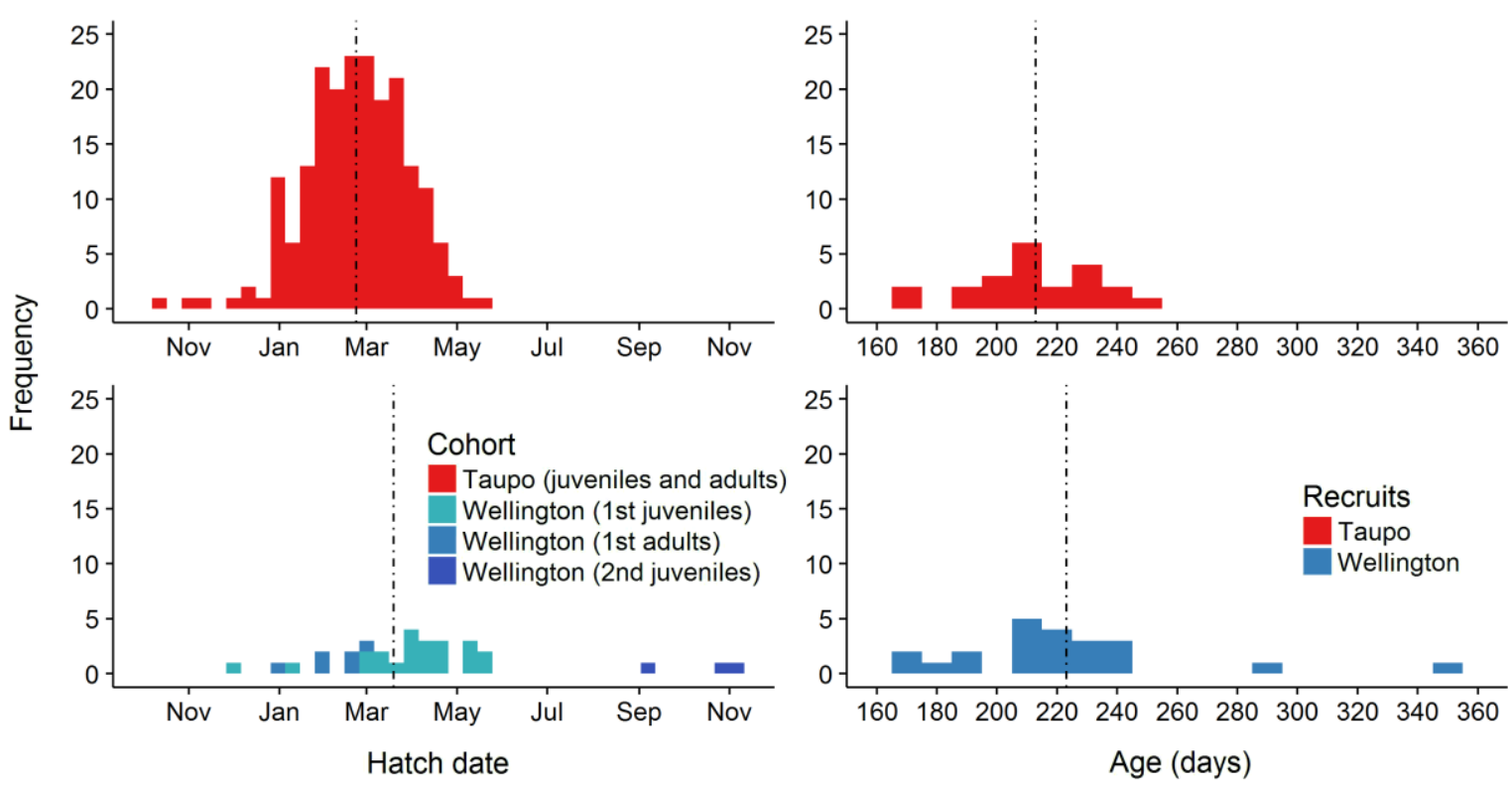

Figure 3.2. Histograms for hatch date and recruitment age between Lake Taupo and Wellington Harbour. Vertical dashed lines show the mean. $2^{\text {nd }}$ year-cohort of juveniles from Wellington were excluded from the mean for hatch date. Bar width $=10$ days.

\subsubsection{Length and morphology covarying with age}

All measured traits (fork length, head length, body depth and eye diameter) increased with age (Table 3.3, Figure 2.3). There was a significant interaction between age and system, with the traits of $R$. retropinna sampled from Wellington Harbour increasing with age at approximately 1.5 to 2 times the rate of those from Lake Taupo. The main effect of system for each trait was significant and had a high magnitude, suggesting that $R$. retropinna sampled from Wellington Harbour were larger for each trait than ones from Lake Taupo, even without the interactive effect of age. 
Table 3.3. ANCOVA results for fork length, head length, body depth and eye diameter with age as covariate. Results with $p<0.05$ are highlighted.

\begin{tabular}{|c|c|c|c|c|c|}
\hline \multirow[t]{3}{*}{$\begin{array}{l}\text { Dependent } \\
\text { variable }\end{array}$} & \multicolumn{5}{|c|}{ Model results } \\
\hline & & Adj. $R^{2}$ & df & F-stat & $p$ value \\
\hline & Model nt & 0.9426 & 3,228 & 1264 & $<0.0001$ \\
\hline \multirow{5}{*}{ Fork length } & Coefficient & $\begin{array}{l}\text { Est. } \\
\text { value }\end{array}$ & $\begin{array}{l}\text { Std. } \\
\text { error }\end{array}$ & $\begin{array}{l}\text { t } \\
\text { value }\end{array}$ & $\begin{array}{l}p \\
\text { value }\end{array}$ \\
\hline & intercept & 17.5174 & 1.5259 & 11.480 & $<0.0001$ \\
\hline & age & 0.0755 & 0.0059 & 12.807 & $<0.0001$ \\
\hline & system(Wellington) & 9.7236 & 2.1873 & 4.445 & $<0.0001$ \\
\hline & age:system(Wellington) & 0.0738 & 0.0081 & 9.154 & $<0.0001$ \\
\hline \multirow{7}{*}{ Head length } & \multirow{2}{*}{ Model fit } & Adj. $R^{2}$ & df & F-stat & $p$ value \\
\hline & & 0.9151 & 3,228 & 830.4 & $<0.0001$ \\
\hline & Coefficient & $\begin{array}{l}\text { Est. } \\
\text { value }\end{array}$ & $\begin{array}{l}\text { Std. } \\
\text { error }\end{array}$ & $\begin{array}{l}t \\
\text { value }\end{array}$ & $\begin{array}{l}p \\
\text { value }\end{array}$ \\
\hline & intercept & 1.0358 & 0.4417 & 2.34 & 0.0199 \\
\hline & age & 0.0230 & 0.0017 & 13.46 & $<0.0001$ \\
\hline & system(Wellington) & 1.9649 & 0.6332 & 3.10 & 0.0022 \\
\hline & age:system(Wellington) & 0.0168 & 0.0023 & 7.17 & $<0.0001$ \\
\hline \multirow{7}{*}{ Body depth } & \multirow{2}{*}{ Model fit } & Adj. $R^{2}$ & df & F-stat & $p$ value \\
\hline & & 0.9106 & 3,228 & 785.4 & $<0.0001$ \\
\hline & Coefficient & $\begin{array}{l}\text { Est. } \\
\text { value }\end{array}$ & $\begin{array}{l}\text { Std. } \\
\text { error }\end{array}$ & $\begin{array}{l}\text { t } \\
\text { value }\end{array}$ & $\begin{array}{l}p \\
\text { value }\end{array}$ \\
\hline & intercept & -0.1111 & 0.3578 & -0.31 & 0.7564 \\
\hline & age & 0.0120 & 0.0014 & 8.70 & $<0.0001$ \\
\hline & system(Wellington) & 1.5755 & 0.5129 & 3.07 & 0.0024 \\
\hline & age:system(Wellington) & 0.0148 & 0.0019 & 7.85 & $<0.0001$ \\
\hline \multirow{7}{*}{ Eye diameter } & \multirow{2}{*}{ Model fit } & Adj. $R^{2}$ & df & F-stat & $p$ value \\
\hline & & 0.9078 & 3,228 & 758.7 & $<0.0001$ \\
\hline & Coefficient & $\begin{array}{l}\text { Est. } \\
\text { value }\end{array}$ & $\begin{array}{l}\text { Std. } \\
\text { error }\end{array}$ & $\begin{array}{l}\mathbf{t} \\
\text { value }\end{array}$ & $\begin{array}{l}p \\
\text { value }\end{array}$ \\
\hline & intercept & 0.3328 & 0.0937 & 3.55 & 0.0005 \\
\hline & age & 0.0056 & 0.0004 & 15.34 & $<0.0001$ \\
\hline & system(Wellington) & 0.5779 & 0.1344 & 4.30 & $<0.0001$ \\
\hline & age:system(Wellington) & 0.0026 & 0.0005 & 5.17 & $<0.0001$ \\
\hline
\end{tabular}



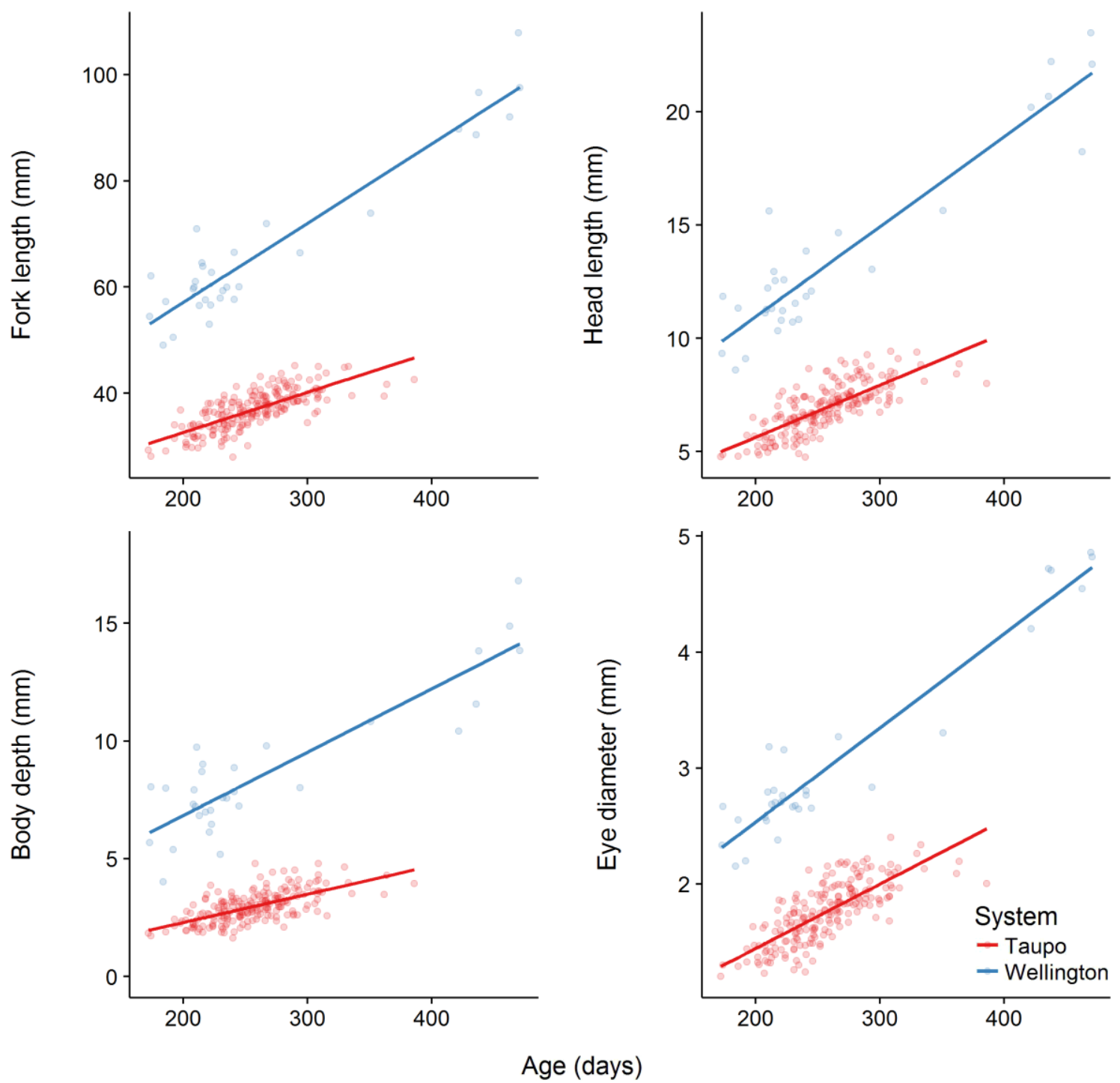

Figure 3.3. Interaction plots showing trait estimates from ANCOVAs for fork length, head length, body depth and eye diameter (with age as a covariate) for Lake Taupo and Wellington Harbour.

\subsubsection{Otolith growth rate differences}

Otolith size-at-age increased when age increased, and was much higher for Wellington than for Lake Taupo (Table 3.4). There was also a strong interaction between age and system, where $R$. retropinna sampled from Wellington Harbour had a much higher growth rate than ones sampled from Lake Taupo. The random effect of 'individual fish (in sample)' provided roughly half of the variation in the model that was not accounted for by fixed effects, while the random effect of 'sample' accounted for only a little of the variation (see chapter 2 for more information on interpreting random effects). 
Table 3.4. Table showing the estimated coefficients for Model 3.1 (for both fixed and random effects). For the fixed effects, the estimated value, standard error, degrees of freedom, $t$-value and $p$ value are given. The estimated values for 'age' and its interaction are slopes. For each random effect, the standard deviation for the intercept and slope are given, as well as the correlation between the intercept and the slope for age. Results with $p<0.05$ are highlighted.

\begin{tabular}{llllll}
\hline Coefficient (fixed) & $\begin{array}{l}\text { Estimated } \\
\text { value }\end{array}$ & $\begin{array}{l}\text { Standard } \\
\text { error }\end{array}$ & df & t-value & $\boldsymbol{p}$ value \\
\hline intercept & 0.567096 & 0.48010 & 39670 & 1.181 & 0.2375 \\
\hline age & 1.0625 & 0.02325 & 39670 & 45.706 & $<0.0001$ \\
\hline systemWellington & -12.3704 & 1.16915 & 10 & -10.581 & $<0.0001$ \\
\hline age:systemWellington & 0.7518 & 0.04598 & 39670 & 16.351 & $<0.0001$ \\
\hline
\end{tabular}

\begin{tabular}{llll}
\hline Random effect & Coefficient & Std. deviation & Correlation \\
\hline \multirow{2}{*}{ Sample } & intercept & 0.82121436 & \\
\cline { 2 - 4 } & age & 0.05977446 & -0.728 \\
\hline \multirow{2}{*}{ Fish (in sample) } & intercept & 5.3462331 & \\
\cline { 2 - 4 } & age & 0.1367901 & -0.168 \\
\hline & residual & 5.7390310 & \\
\hline
\end{tabular}

\subsubsection{Temperature and chlorophyll a comparison}

Water temperatures in Lake Taupo varied more from late-2014 to 2015 than they did in Wellington Harbour. They also 'lagged behind' by approximately a month. Chlorophyll a levels in Lake Taupo greatly increased from March to November but were otherwise similar to levels in Wellington Harbour, which remained fairly constant. 


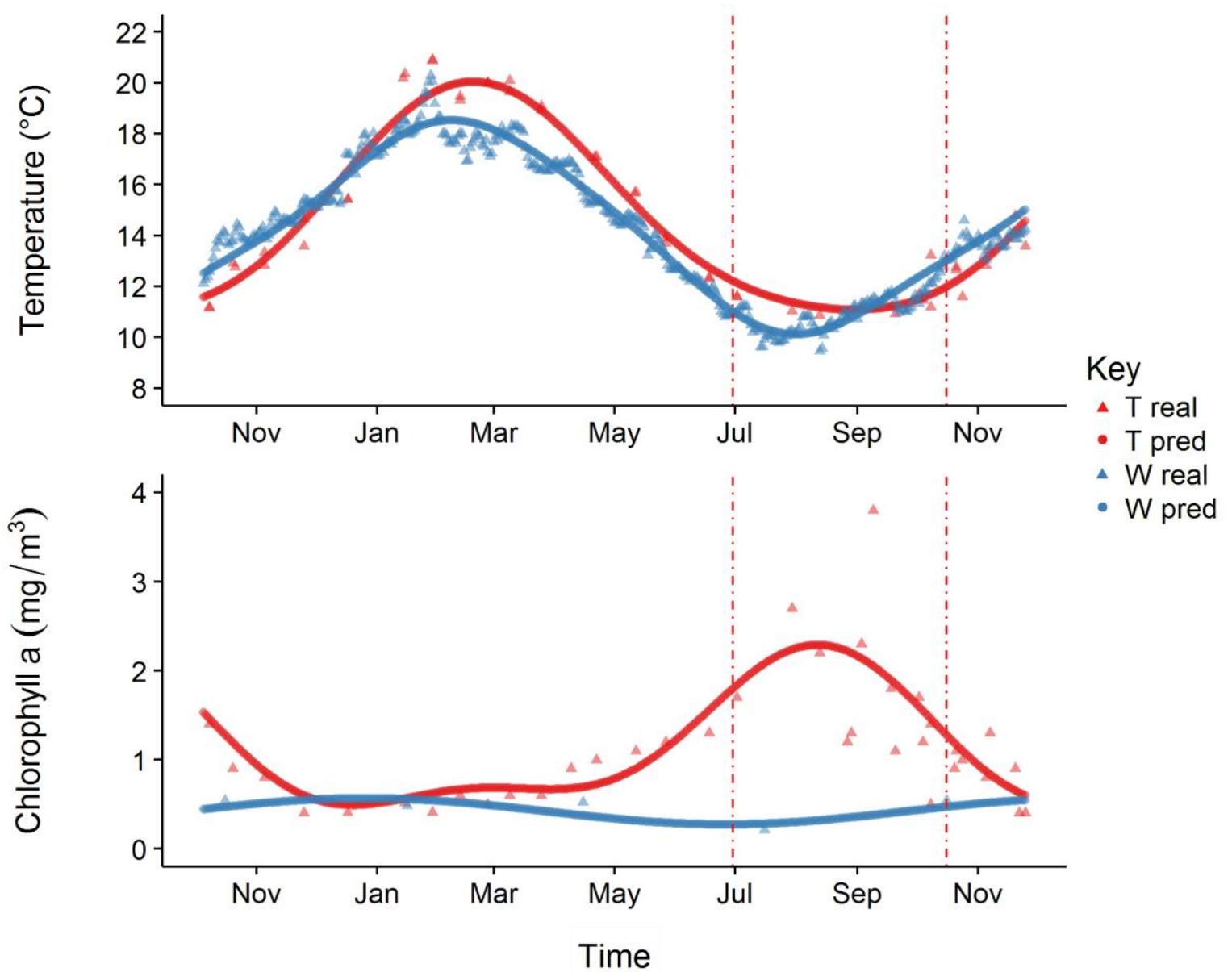

Figure 3.4. Plots showing real and predicted values for water temperature $\left({ }^{\circ} \mathrm{C}\right)$ and chlorophyll a $\left(\mathrm{mg} / \mathrm{m}^{3}\right)$ in Lake Taupo and Wellington Harbour from late-2014 to 2015. The area bound by dashed lines indicates the period of winter mixing for Lake Taupo (Wellington Harbour is always mixed). Real values for temperature and chlorophyll a in Lake Taupo after 27/08/2015 are combined data from 2012, 2013 and 2014. Real values for chlorophyll a Wellington Harbour were measured in 1998-1999. All other real values were collected at the times indicated. Predicted values come from sigmoidal models fitted to the real values (Model 3.2).

\subsubsection{Increment width comparison}

With a few exceptions, most of the fixed effects from the model (and their interactions) had a significant effect on otolith width-at-age (Table 3.5). Many of the interactions in the model are difficult to interpret, although some can be disregarded given their extremely small magnitude (i.e. <0.0010). Importantly, there were many significant interactions between system and other variables, as well as a large main effect, suggesting that both intrinsic (age) and extrinsic (time, temperature and chlorophyll a) have different effects on otolith growth for Lake 
Taupo and Wellington Harbour. All the random effects accounted for a useful component of the variation, and showed a negative correlation between variation in intercepts and slopes (see chapter 2 for more information on interpreting random effects).

The predicted values taken from Model 3.3 track well with a running average of increment widths taken from the raw otolith increment width data (Figure 3.5). $R$. retropinna sampled from Wellington Harbour grew faster than ones from Lake Taupo regardless of season (i.e. their increments were consistently always wider), and that their growth rate did not slow to the same extent in winter. 
Table 3.5. Table showing the estimated coefficients for Model 3.3 (for both fixed and random effects), applied to samples from Lake Taupo and Wellington Harbour. All estimated values apart from the intercept are slopes. Variation for intercept and slope are given for each random effect, as well as the correlation between the intercept and slope. Results with $p<0.05$ are highlighted. PTO.

\begin{tabular}{|c|c|c|c|c|c|}
\hline Coefficient & $\begin{array}{l}\text { Est. } \\
\text { value }\end{array}$ & $\begin{array}{l}\text { Std. } \\
\text { error }\end{array}$ & df & t value & $p$ value \\
\hline intercept & 1.4750 & 0.4067 & 57037 & 3.627 & 0.0003 \\
\hline systemWellington & 26.152 & 5.634979 & 10 & 4.641 & 0.0009 \\
\hline age & -0.0819 & 0.003155 & 57037 & -25.95 & $<0.0001$ \\
\hline time & -0.0084 & 0.0014 & 57037 & -5.965 & $<0.0001$ \\
\hline temp & -0.0246 & 0.0248 & 57037 & -0.992 & 0.3214 \\
\hline chl & 6.2974 & 0.4853 & 57037 & 12.98 & $<0.0001$ \\
\hline systemWellington:age & -0.0136 & 0.0302 & 57037 & -0.451 & 0.6520 \\
\hline systemWellington:time & -0.1001 & 0.0187 & 57037 & -5.338 & $<0.0001$ \\
\hline age:time & 0.0004 & 0.0001 & 57037 & 30.186 & $<0.0001$ \\
\hline systemWellington:temp & -2.0627 & 0.1535 & 57037 & -13.44 & $<0.0001$ \\
\hline age:temp & 0.0056 & 0.0002 & 57037 & 23.114 & $<0.0001$ \\
\hline time:temp & 0.0003 & 0.0001 & 57037 & 3.5046 & 0.0005 \\
\hline systemWellington:chl & -41.413 & 13.851 & 57037 & -2.990 & 0.0028 \\
\hline age:chl & 0.0259 & 0.0049 & 57037 & 5.2817 & $<0.0001$ \\
\hline time:chl & -0.0358 & 0.0018 & 57037 & -19.792 & $<0.0001$ \\
\hline temp:chl & -0.5197 & 0.0376 & 57037 & -13.832 & $<0.0001$ \\
\hline systemWellington:age:time & 0.0001 & 0.0001 & 57037 & 0.674 & 0.5005 \\
\hline systemWellington:age:temp & -0.0001 & 0.0015 & 57037 & -0.035 & 0.9724 \\
\hline systemWellington:time:temp & 0.0086 & 0.0004 & 57037 & 20.773 & $<0.0001$ \\
\hline age:time:temp & 0.0000 & 0.0000 & 57037 & -24.05 & $<0.0001$ \\
\hline systemWellington:age:chl & 0.2969 & 0.0887 & 57037 & 3.347 & 0.0008 \\
\hline systemWellington:time:chl & 0.2185 & 0.0626 & 57037 & 3.490 & 0.0005 \\
\hline age:time:chl & 0.0001 & 0.0000 & 57037 & 5.392 & $<0.0001$ \\
\hline systemWellington:alltemp:chl & 3.4595 & 0.4869 & 57037 & 7.105 & $<0.0001$ \\
\hline age:temp:chl & -0.0007 & 0.0004 & 57037 & -1.442 & 0.1494 \\
\hline time:temp:chl & 0.0032 & 0.0002 & 57037 & 17.800 & $<0.0001$ \\
\hline systemWellington:age:time:temp & 0.0000 & 0.0000 & 57037 & -4.405 & $<0.0001$ \\
\hline systemWellington:age:time:chl & -0.0012 & 0.0003 & 57037 & -3.791 & 0.0002 \\
\hline systemWellington:age:temp:chl & -0.0118 & 0.0035 & 57037 & -3.359 & 0.0008 \\
\hline systemWellington:time:temp:chl & -0.0183 & 0.0022 & 57037 & -8.392 & $<0.0001$ \\
\hline age:time:temp:chl & 0.0000 & 0.0000 & 57037 & -8.295 & $<0.0001$ \\
\hline systemWellington:age:time:temp:chl & 0.0001 & 0.0000 & 57037 & 8.196 & $<0.0001$ \\
\hline
\end{tabular}




\begin{tabular}{llll}
\hline Random effect & Coefficient & Std. deviation & Correlation \\
\hline \multirow{2}{*}{ Sample } & intercept & 0.349363946 & \\
\cline { 2 - 4 } & age & 0.002581763 & -0.996 \\
\hline \multirow{2}{*}{ Fish (in sample) } & intercept & 0.364565768 & \\
\cline { 2 - 4 } & age & 0.003032227 & -0.952 \\
\hline & residual & 0.295835596 & \\
\hline
\end{tabular}

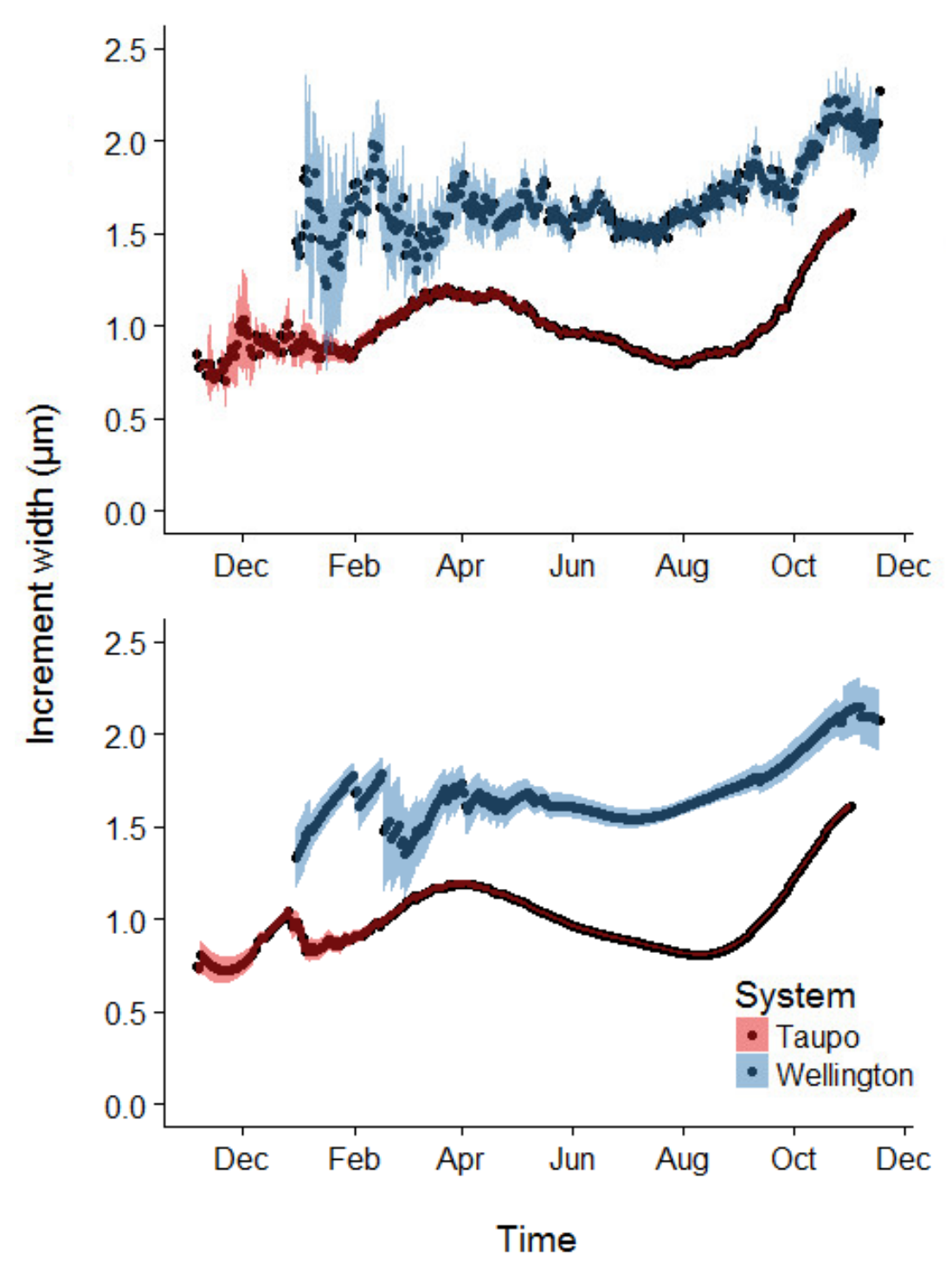

Figure 3.5. Plots showing raw (top) and predicted (bottom) increment widths against time for Lake Taupo and Wellington Harbour. Raw values are the mean increment widths (dots) and their S.E. (cloud) for each date. Predicted values are the mean fitted values (dots) from Model 2.3 and their S.E. (cloud) for each date. Note that low sample sizes early in the hatching season are the likely causes of the high initial S.E. for the raw values, and of the sudden 'jumps' in the predicted values. 


\subsection{Discussion}

I found that landlocked and sea-going morphs may share common hatching and recruitment phenologies. However the length and morphological traits of sea-going morphs increase with age significantly faster. Furthermore, otolith increments for sea-going morphs were consistently larger immediately from hatching. This may suggest that there are different intrinsic effects (e.g. genetic, epigenetic, maternal) driving these differences between morphs (Green \& McCormick 2005). For example, egg size (maternal effect) and egg environment (partly extrinsic, partly epigenetic) may be important for pre-setting development trajectories in fish (Brooks et al. 1997). Teasing apart these possible mechanisms behind the ability of $R$. retropinna to modulate its own and its progeny's development trajectories would make for an elegant experimental study.

I also found evidence that extrinsic factors may have differing effects on individual variation between Lake Taupo and Wellington Harbour. Winter otolith increments were narrower for $R$. retropinna sampled from Lake Taupo and had 'beached bands', suggesting greater physiological stress for this population than for the one from Wellington Harbour. One explanation for this may be to do with food abundance for $R$. retropinna. Lake Taupo is oligotrophic and becomes strongly mixed during the winter - leading to poor zooplankton abundance during this period (Verburg \& Albert 2016), as often occurs in other lakes (Winder \& Schindler 2004) and in marine systems (Platt et al. 2003). Pelagic $R$. retropinna feed primarily on zooplankton (Rowe et al. 2002), and a lack of food over winter is a common cause of fish mortality and stress (Jolley et al. 2013). Detailed study on the effect of zooplankton levels on the abundance and distribution of $R$. retropinna in Lake Taupo would be an important next step in testing this hypothesis, which could have important implications for fisheries management in Lake Taupo.

A growing-degree day framework (designed for studies of plant growth and development) could provide an alternative approach to exploring the effect of environmental variables on otolith growth histories. Here, an accumulation of temperatures-at-age (or other environmental variable) could be used to predict fish length-at-age (Neuheimer \& Taggart 2007) or otolith size-at-age. 


\section{CHAPTER 4: GENERAL CONCLUSIONS}

\subsection{Summary of results}

\subsubsection{Hatching and recruitment phenology.}

I found that the ages of $R$. retropinna within Lake Taupo differed significantly between the southern and eastern/western regions. While this could imply different regional hatching and/or recruitment phenologies, it is most likely the artefact of a spatial imbalance in larval supply to the shores of the lake (Jolly 1967), possibly in conjunction with more intense predation pressure on smaller/younger $R$. retropinna in the western region (Stephens 1984).

On the other hand, the overall $R$. retropinna population of Lake Taupo shared fairly similar hatching and recruitment phenologies with the Wellington Harbour population. This suggests that the key phenological characteristics of $R$. retropinna could be shared between landlocked and sea-going populations (however they may still vary depending on latitude).

\subsubsection{Effect of hatch date vs region on growth rate}

In Wellington Harbour, my sample size was too small to look for an effect of hatch date on otolith growth. However given the relative lack of seasonal variation in otolith increment widths, hatch date may only have a relatively minor effect on otolith growth rates for $R$. retropinna in this system.

In Lake Taupo, I found a significant effect of hatch date on otolith growth, where individuals that hatched later in the season grew slightly faster. I also found that the east and west regions experienced greater rates of growth than the south. However the interactions between hatch date and age were significantly different between regions, especially in the south where the effect of this interaction on otolith growth rate was largely negligible. 


\subsubsection{Morphological variation}

I found some morphological variation within Lake Taupo. $R$. retropinna from the south had smaller heads relative to body length, and smaller heads, shallower bodies and smaller eyes relative to age. This suggests that southern $R$. retropinna had experienced a lower somatic growth rate, however as my results do not entirely rule out the possibility that the growth of $R$. retropinna is non-isometric this may be partly die to the greater age of the southern $R$. retropinna.

Differences between Lake Taupo and Wellington Harbour were harder to compare because of a lack of overlap in length, meaning I could use only age as a covariate. Length and all morphological variables increased faster with age for $R$. retropinna sampled from Wellington Harbour than in Lake Taupo, indicating a somatic growth rate 1.5 to 2 times faster.

\subsubsection{Environmental variables and increment widths}

Increment widths for Wellington Harbour were consistently higher than those for Lake Taupo, and they dropped less during winter. Chlorophyll a was an important effect in the Lake Taupo model but not the Wellington Harbour. This is likely because chlorophyll a levels did not vary much in Wellington Harbour. This may indicate that Wellington Harbour supports higher densities of zooplankton than Lake Taupo, especially during the winter when zooplankton may be swept out of the euphotic zone (this cannot happen in Wellington Harbour as it is too shallow). Then in spring, Lake Taupo stratifies again, zooplankton densities rebound (as they graze down phytoplankton densities - indicated by reduced levels of chlorophyll a) and $R$. retropinna otolith increment widths increase in size once more.

\subsection{Implications for population dynamics and management}

I conclude that the population dynamics of $R$. retropinna in Lake Taupo are probably primarily driven by food availability. Until they become vulnerable to salmonids at $25 \mathrm{~mm}$ fork length (Stephens 1984), R. retropinna have no predators; and larval dispersal in a lake is likely less challenging than in a marine environment. Furthermore, I found evidence that $R$. retropinna underwent physiological stress 
during the winter, likely due to a lack of food. I expect that the Lake Taupo population of $R$. retropinna is primarily bottom-up regulated (by food availability), especially during the winter. Food abundance in the lake during winter may play a key role in determining the annual recruitment success of $R$. retropinna, which in turn is likely to be an important factor in determining the annual success of the lake's salmonid fishery.

In contrast, predators and dispersal challenges may have greater relative importance in Wellington Harbour, where many more predator species exist and larvae dispersing beyond the harbour will likely face recruitment challenges. In order to understand this population's abundance and population dynamics, much more study is required. 


\section{REFERENCES}

Anderson, T. W., \& Darling, D. A. (1954). A test of goodness of fit. Journal of the American statistical association, 49(268), 765-769.

Benton, T. G., Plaistow, S. J., \& Coulson, T. N. (2006). Complex population dynamics and complex causation: devils, details and demography. Proceedings of the Royal Society of London B: Biological Sciences, 273(1591), 1173-1181.

Blair, J. (2012). Factors controlling common smelt abundance and rainbow trout growth in the Rotorua Lakes, New Zealand. PhD Thesis, University of Waikato, Hamilton.

Bogner, D. M., Kaemingk, M. A., \& Wuellner, M. R. (2016). Consequences of Hatch Phenology on Stages of Fish Recruitment. Plos One, 11(10), e0164980.

Booker, J. R. (2000). Smelt (Retropinna retropinna) displacement and population dynamics in the Waikato River system.

Booth, J. D. (1975). Seasonal and tidal variations in the hydrology of Wellington Harbour. New Zealand journal of marine and freshwater research, 9(3), 333-354.

Breusch, T. S., \& Pagan, A. R. (1979). A simple test for heteroscedasticity and random coefficient variation. Econometrica: Journal of the Econometric Society, 1287-1294.

Brooks, S., Tyler, C. R., \& Sumpter, J. P. (1997). Egg quality in fish: what makes a good egg? Reviews in Fish Biology and Fisheries, 7(4), 387-416.

Burstall, P. J. (1950). Smelt in New Zealand. N.Z. Fishing and Shooting Gazette, 18(3), 14-15.

Campana, S. E., \& Neilson, J. D. (1985). Microstructure of fish otoliths. Canadian Journal of Fisheries and Aquatic Sciences, 42(5), 1014-1032.

Caswell, H. (2001). Matrix population models: Wiley Online Library.

Charlesworth, B. (1980). Evolution in age-structured populations (Vol. 2).

Conner, M. M., \& White, G. C. (1999). Effects of individual heterogeneity in estimating the persistence of small populations. Natural Resource Modeling, 12(1), 109-127.

Cryer, M. (1988). Predatory impact of New Zealand smelt on natural populations of zooplankton. Verh. Int. Ver. Limnol, 23, 1778-1783.

Dahlberg, M. D. (1979). A review of survival rates of fish eggs and larvae in relation to impact assessments. Marine Fisheries Review, 41(3), 1-12.

Forsyth, D., Downes, M., Gibbs, M., Kemp, L., McCallum, I., MacKenzie, L., \& Payne, G. (1983). Aspects of the limnology of Lake Rotongaio. New Zealand journal of marine and freshwater research, 17(4), 423-435.

Goodwin, D. H., Schöne, B. R., \& Dettman, D. L. (2003). Resolution and fidelity of oxygen isotopes as paleotemperature proxies in bivalve mollusk shells: models and observations. Palaios, 18(2), 110-125.

Green, B. S., \& McCormick, M. I. (2005). Maternal and paternal effects determine size, growth and performance in larvae of a tropical reef fish. Marine Ecology Progress Series, 289, 263272.

Haldane, J. (1924). A mathematical theory of natural selection and artificial selection: Part 1. Cambridge Phil. Soc. Trans, 23, 838-844. 
Hammer, M. P., Adams, M., Unmack, P. J., \& Walker, K. F. (2007). A rethink on Retropinna: conservation implications of new taxa and significant genetic sub-structure in Australian smelts (Pisces: Retropinnidae). Marine and Freshwater Research, 58(4), 327-341.

Harper, J., \& White, J. (1974). The demography of plants. Annual review of Ecology and Systematics, 419-463.

Helson, J. G., Pledger, S., \& Gardner, J. P. (2007). Does differential particulate food supply explain the presence of mussels in Wellington Harbour (New Zealand) and their absence on neighbouring Cook Strait shores? Estuarine, Coastal and Shelf Science, 72(1), 223-234.

Hendry, A. P., Taylor, E. B., \& McPhail, J. D. (2002). Adaptive divergence and the balance between selection and gene flow: lake and stream stickleback in the Misty system. Evolution, 56(6), 1199-1216.

Houde, E. D. (1989). Comparative growth, mortality, and energetics of marine fish larvae: Temperature and implied latitudinal effects. Fishery Bulletin, 87(3), 471-495.

Jolley, J. C., Kaemingk, M. A., Willis, D. W., \& Holland, R. S. (2013). Overwinter Mortality of Sympatric Juvenile Bluegill and Yellow Perch in Mid-Temperate Sandhill lakes, Nebraska, USA. Open Fish Science Journal, 6, 58-70.

Jolly, V. H. (1967). Observations on the smelt Retropinna lacustris Stokell. New Zealand journal of science, 10, 330-355.

Kaemingk, M. A., Jolley, J. C., Willis, D. W., \& Chipps, S. R. (2012). Priority effects among young-ofthe-year fish: reduced growth of bluegill sunfish (Lepomis macrochirus) caused by yellow perch (Perca flavescens)? Freshwater Biology, 57(4), 654-665.

Kaemingk, M. (2015). [Spatial recruitment differences between harbour and coastal populations of Galaxias maculatus]. Unpublished raw data.

Keeling, M. J., \& Rohani, P. (2008). Modeling infectious diseases in humans and animals: Princeton University Press.

Kendall, B. E., Fox, G. A., Fujiwara, M., \& Nogeire, T. M. (2011). Demographic heterogeneity, cohort selection, and population growth. Ecology, 92(10), 1985-1993.

Kern, S., Ackermann, M., Stearns, S. C., \& Kawecki, T. J. (2001). Decline in offspring viability as a manifestation of aging in Drosophila melanogaster. Evolution, 55(9), 1822-1831.

Langerhans, R. B., Layman, C. A., Langerhans, A. K., \& Dewitt, T. J. (2003). Habitat-associated morphological divergence in two Neotropical fish species. Biological Journal of the Linnean Society, 80(4), 689-698.

Langerhans, R. B., \& Reznick, D. N. (2010). Ecology and evolution of swimming performance in fishes: predicting evolution with biomechanics. Fish locomotion: an eco-ethological perspective (eds Domenici P., Kapoor BG), 200-248.

Leslie, P. H. (1945). On the use of matrices in certain population mathematics. Biometrika, 33(3), 183-212.

Marascuilo, L. A., \& Levin, J. R. (1970). Appropriate post hoc comparisons for interaction and nested hypotheses in analysis of variance designs: The elimination of type IV errors. American Educational Research Journal, 397-421.

McDowall, R. (2007). On amphidromy, a distinct form of diadromy in aquatic organisms. Fish and fisheries, 8(1), 1-13.

McDowall, R. M. (1979). Fishes of the family Retropinnidae (Pisces: Salmoniformes) - a taxonomic revision and synopsis. Journal of the Royal Society of New Zealand, 9(1), 85-121.

McDowall, R. M. (1990). New Zealand freshwater fishes: a natural history and guide: Raupo. 
Metcalf, C. J. E., \& Pavard, S. (2007). Why evolutionary biologists should be demographers. Trends in Ecology \& Evolution, 22(4), 205-212.

Mooij, W., Lammens, E., \& Densen, W. V. (1994). Growth rate of 0+ fish in relation to temperature, body size, and food in shallow eutrophic Lake Tjeukemeer. Canadian Journal of Fisheries and Aquatic Sciences, 51(3), 516-526.

Neilson, C. (2015). [Spatial and temporal variation in the recruitment dynamics of an amphidromous fish]. Unpublished raw data.

Neuheimer, A. B., \& Taggart C. T. (2007). The growing degree-day and fish size-at-age: the overlooked metric. Canadian Journal of Fisheries and Aquatic Sciences, 64(2), 375-385.

Noonburg, E. G., Chen, A., Shima, J. S., \& Swearer, S. E. (2015). Demographic heterogeneity and the dynamics of open populations. Ecology, 96(5), 1159-1165.

Northcote, T., \& Ward, F. (1985). Lake resident and migratory smelt, Retropinna retropinna (Richardson), of the lower Waikato River system, New Zealand. Journal of Fish Biology, 27(2), 113-129.

Norton, H. (1928). Natural selection and Mendelian variation. Proceedings of the London Mathematical Society, 2(1), 1-45.

Ozgul, A., Tuljapurkar, S., Benton, T. G., Pemberton, J. M., Clutton-Brock, T. H., \& Coulson, T. (2009). The dynamics of phenotypic change and the shrinking sheep of St. Kilda. Science, 325(5939), 464-467.

Pankhurst, N., \& Montgomery, J. (1994). Uncoupling of visual and somatic growth in the rainbow trout Oncorhynchus mykiss. Brain, behavior and evolution, 44(3), 149-155.

Pannella, G. (1971). Fish otoliths: daily growth layers and periodical patterns. Science, 173(4002), 1124-1127.

Pinheiro J, B. D., DebRoy S, Sarkar D, R Core Team. (2016). nlme: Linear and Nonlinear Mixed Effects Models.

Platt, T., Fuentes-Yaco, C., \& Frank, K. T. (2003). Marine ecology: spring algal bloom and larval fish survival. Nature, 423(6938), 398-399.

Reibisch, J. (1899). Über die Eizahl bei Pleuronectes platessa und die Altersbestimmung dieser Form aus den Otolithen. The number of eggs in the Pleuronectes platessa and the fixing of its age by means of the otolith). Translated by ATA Dobson. Wissenschaftliche Meeresuntersuchungen NF Abt. Kiel, 4, 231-248.

Rosario-Martinez (2015). phia: Post-Hoc Interaction Analysis. R package version 0.2-1. https://CRAN.R-project.org/package=phia

Roughgarden, J. (1971). Density-dependent natural selection. Ecology, 52(3), 453-468.

Rowe, D. K. (1993). Disappearance of koaro, Galaxias brevipinnis, from Lake Rotopounamu, New Zealand, following the introduction of smelt, Retropinna retropinna. Environmental Biology of Fishes, 36(4), 329-336.

Rowe, D. K., Smith, J., \& Williams, E. (2002). Effects of turbidity on the feeding ability of adult, riverine smelt (Retropinna retropinna) and inanga (Galaxias maculatus). New Zealand journal of marine and freshwater research, 36(1), 143-150.

RStudio. (2015). RStudio: Integrated Development for R. RStudio, Inc., Boston, MA.

Schluter, D., \& McPhail, J. D. (1992). Ecological character displacement and speciation in sticklebacks. American Naturalist, 85-108. Scholz and Zhu (2016). kSamples: K-Sample Rank Tests and their Combinations. R package version 1.2-4. https://CRAN.Rproject.org/package $=k$ Samples 
Scott, B. E., Marteinsdottir, G., Begg, G. A., Wright, P. J., \& Kjesbu, O. S. (2006). Effects of population size/age structure, condition and temporal dynamics of spawning on reproductive output in Atlantic cod (Gadus morhua). Ecological Modelling, 191(3), 383415.

Stephens, T. (1984). Smelt (Retropinna retropinna) population dynamics and predation by rainbow trout (Salmo gairdneri) in Lake Taupo. University of Waikato.

Stover, J. P., Kendall, B. E., \& Fox, G. A. (2012). Demographic heterogeneity impacts densitydependent population dynamics. Theoretical Ecology, 5(2), 297-309.

Strickland, R. (1993). Pre-European transfer of smelt in the Rotorua-Taupo area, New Zealand. Journal of the Royal Society of New Zealand, 23(1), 13-28.

Tana, R. \& Tempero, G. 2013. Life-history of Lake Horowhenua common smelt: analysis of otoltih chemistry and vertebral counts. Client report prepared for Horizons Regional Council. Environmental Reasearch Institute Report No. 16, The University of Waikato, Hamilton.

Tonkin, Z., King, A., \& Ramsey, D. (2008). Otolith increment width responses of juvenile Australian smelt Retropinna semoni to sudden changes in food levels: the importance of feeding history. Journal of Fish Biology, 73(4), 853-860.

Tonkin, Z., King, A., \& Robertson, A. (2008). Validation of daily increment formation and the effects of different temperatures and feeding regimes on short-term otolith growth in Australian smelt Retropinna semoni. Ecology of Freshwater Fish, 17(2), 312-317.

Tonkin, Z. D., King, A. J., Robertson, A. I., \& Ramsey, D. S. (2011). Early fish growth varies in response to components of the flow regime in a temperate floodplain river. Freshwater Biology, 56(9), 1769-1782.

Tzeng, W. N., \& Yu, S. Y. (1992). Effects of starvation on the formation of daily growth increments in the otoliths of milkfish, Chanos chanos (Forsskål), larvae. Journal of Fish Biology, 40(1), 39-48.

Vaupel, J. W., Manton, K. G., \& Stallard, E. (1979). The impact of heterogeneity in individual frailty on the dynamics of mortality. Demography, 16(3), 439-454.

Vaupel, J. W., \& Yashin, A. I. (1985). Heterogeneity's ruses: some surprising effects of selection on population dynamics. The American Statistician, 39(3), 176-185.

Verburg, P., \& Albert, A. (2016). Lake Taupo long-term monitoring programme: 2014-2015 (Document number: 8768881). Retrieved from https://www.waikatoregion.govt.nz/assets/PageFiles/Lake\%20Taupo\%20long\%20term\%2 Omonitoring\%20programme\%202014-2015.pdf

Vincent, W., Forsyth, D., \& Howard-Williams, C. (1983). Physics of the lake-waves, mixing, currents, and clarity. Lake Taupo: Ecology of a New Zealand Lake, DSIR Information Series(158).

Visser, M. E., \& Both, C. (2005). Shifts in phenology due to global climate change: the need for a yardstick. Proceedings of the Royal Society of London B: Biological Sciences, 272(1581), 2561-2569.

Vogel, S. (1994). Life in moving fluids: the physical biology of flow: Princeton University Press.

Ward, F., \& Boubee, J. (1996). Effect of age at maturity on life-span and generation time of New Zealand common smelt, Retropinna retropinna (Richardson). Canadian Journal of Fisheries and Aquatic Sciences, 53(3), 467-473.

Ward, F., Northcote, T., \& Boubee, J. (2005). The New Zealand common smelt: biology and ecology. Journal of Fish Biology, 66(1), 1-32. 
Ward, F. J., Boubee, J. A., Meredith, A. S., \& Northcote, T. G. (1989). Characteristics of common smelt, Retropinna retropinna (Richardson), of the Waikato River system. New Zealand journal of marine and freshwater research, 23(3), 345-355.

Weisberg, S., Spangler, G., \& Richmond, L. S. (2010). Mixed effects models for fish growth. Canadian Journal of Fisheries and Aquatic Sciences, 67(2), 269-277.

White, E., \& Downes, M. (1977). Preliminary assessment of nutrient loads on Lake Taupo, New Zealand. New Zealand journal of marine and freshwater research, 11(2), 341-356.

Wilson, E. O., \& MacArthur, R. H. (1967). The theory of island biogeography. Princeton, NJ.

Winder, M., \& Schindler, D. E. (2004). Climatic effects on the phenology of lake processes. Global Change Biology, 10(11), 1844-1856.

Zeileis \& Hothorn (2002). Diagnostic Checking in Regression Relationships. R News 2(3), 7-10. URL http://CRAN.R-project.org/doc/Rnews/ 